\title{
Structures of the Cyanobacterial Phycobilisome
}

Paul V. Sauer ${ }^{* 1,2}$ (0000-0001-7204-5863), Maria Agustina Dominguez-Martin*3,4,5 (0000-0002-

David Bina $^{6,7}$ (0000-0002-9259-4218), Basil J. Greber ${ }^{1,4,8}$ (0000-0001-9379-7159), Eva Nogales ${ }^{1,2,4,9}$

(0000-0002-9977-8482)

$9 \quad{ }^{1}$ QB3 Institute, University of California, Berkeley, CA, USA

$10{ }^{2}$ Howard Hughes Medical Institute, University of California, Berkeley, CA, USA

$11{ }^{3}$ Environmental Genomics and Systems Biology Division, Lawrence Berkeley National Laboratory,

12 Berkeley, CA 94720, USA.

$13{ }^{4}$ Molecular Biophysics and Integrated Bioimaging Division, Lawrence Berkeley National Laboratory,

14 Berkeley, CA 94720, USA.

$15{ }^{5}$ MSU-DOE Plant Research Laboratory, Michigan State University, East Lansing, MI 48824, USA.

$16{ }^{6}$ Faculty of Science, University of South Bohemia, Ceske Budejovice, Czech Republic

$17{ }^{7}$ Biology Centre of the Czech Academy of Sciences, Ceske Budejovice, Czech Republic

$18{ }^{8}$ Present address: Division of Structural Biology, Institute of Cancer Research, London, UK

$19{ }^{9}$ Department of Molecular and Cellular Biology, University of California, Berkeley, CA, USA.

$20{ }^{10}$ Department of Biochemistry and Molecular Biology, Michigan State University, East Lansing, MI 48824,

21 USA

$22 \quad{ }^{(*)}$ These authors contributed equally to this work.

$23 \quad{ }^{(\#)}$ Address correspondence to: ckerfeld@1bl.gov

24 The author responsible for distribution of materials integral to the findings presented in this article is: Cheryl

25 A. Kerfeld (ckerfeld@lbl.gov). 
bioRxiv preprint doi: https://doi org/10.1101/2021.11.15.468712: this version posted November 15,2021 . The copyright holder for this preprint (which was not certified by peer review) is the author/funder, who has granted bioRxiv a license to display the preprint in perpetuity. It is made available under aCC-BY-NC-ND 4.0 International license.

Structures of the Cyanobacterial Phycobilisome

\section{Abstract}

29 The phycobilisome is an elaborate antenna that is responsible for light-harvesting in cyanobacteria and

30 red-algae. This large macromolecular complex captures incident sunlight and transfers the energy via

31 a network of pigment molecules called bilins to the photosynthetic reaction centers. The phycobilisome

32 of the model organism Synechocystis PCC 6803 consists of a core to which six rods are attached but

33 its detailed molecular architecture and regulation in response to environmental conditions is not well

34 understood. Here we present cryo-electron microscopy structures of the 6.2 MDa phycobilisome from

35 Synechocystis PCC 6803 resolved at $2.1 \AA$ (rods) to $2.7 \AA$ (core), revealing three distinct

36 conformations, two previously unknown. We found that two of the rods are mobile and can switch

37 conformation within the complex, revealing a layer of regulation not described previously. In addition,

38 we found a novel linker protein in the structure, that may represent a long-sought subunit that tethers

39 the phycobilisome to the thylakoid membrane. Finally, we show how excitation energy is transferred

40 within the phycobilisome and correlate our structures with known spectroscopic properties. Together,

41 our results provide detailed insights into the biophysical underpinnings of cyanobacterial light

42 harvesting and lay the foundation for bioengineering of future phycobilisome variants and artificial

43 light harvesting systems. 
Structures of the Cyanobacterial Phycobilisome

53 Cyanobacteria are the most abundant and ecophysiologically diverse primary producers on Earth.

54 Oxygenic photosynthesis is an ancient cyanobacterial innovation that allowed complex life to emerge ${ }^{1}$,

55 and today these organisms are being established as platforms for green biotechnologies ${ }^{2}$.

56 Cyanobacterial phycobilisomes (PBSs) $)^{3-5}$ are massive pigment-protein complexes that can constitute

57 up to half of the soluble protein content of the cell ${ }^{6}$. The two major PBS substructures, the core and

58 the rod, are composed of phycobiliproteins, and colorless linker proteins (LPs) ${ }^{7}$. Phycobilin pigments

59 are covalently bound to the phycobiliproteins ${ }^{8-14}$, which assemble into disc-like trimers $(\alpha \beta)_{3}$ or

60 hexamers $(\alpha \beta)_{6}$. These discs are chained together in the rods and core cylinders by LPs and organized

61 into a complete $\mathrm{PBS}^{15-17}$. The association of pigments with protein tunes the pigments' energetic

62 properties to establish an energy cascade to the photosynthetic reaction centers that is both extremely

63 fast and highly efficient (ca. 95\%) ${ }^{18,19}$. Four morphological types of PBS are known:

64 hemiellipsoidal ${ }^{16,20,21}$, block-type ${ }^{15}$, hemidiscoidal ${ }^{10,22-25}$ and bundle-type ${ }^{26}$. Synechocystis PCC 6803

65 is the primary model system for molecular and spectroscopic studies ${ }^{27}$ containing the most widespread

66 type of PBS, the hemidiscoidal ${ }^{8,22,25,28,29}$, which is also the evolutionary antecedent of all types of

67 PBS $^{15}$. We report three cryo-electron microscopy (cryo-EM) structures of the 6.2 MDa PBS from

68 Synechocystis PCC 6803, representing distinct conformers of rod arrangements: the canonical 'up-up'

69 (2.7 $\AA)$, and two previously undescribed, 'up-down' (2.8 $\AA$ ), and 'down-down' (3.5 $\AA$ ) conformations.

70 We also describe the structure of all the linkers, one of them previously unknown, the arrangement of

71 all bilins, and elucidate the likely energy transfer pathway.

\section{Structural overview}

73 Purified and intact PBS complex was biotinylated and subjected to cryo-EM using streptavidin affinity

74 grids $^{30}$ to reduce preferential particle orientations and to increase stability (Methods, Extended Data

75 Fig. 1, Extended Data Table 1, 2). We determined the structure of three distinct PBS conformations at

76 resolutions ranging from 2.7 to $3.5 \AA$ for the entire complexes, enabling us to build all pigments and 
bioRxiv preprint doi: https://doi org/10.1101/2021.11 15.468712; this version posted November 15,2021 . The copyright holder for this preprint (which was not certified by peer review) is the author/funder, who has granted bioRxiv a license to display the preprint in perpetuity. It is made available under aCC-BY-NC-ND 4.0 International license.

Structures of the Cyanobacterial Phycobilisome

77 protein chains (Fig. 1, Extended Data Fig. 2, 3, and Extended Data Table 3). As previously reported ${ }^{22}$,

78 the rods are flexible in nature and therefore appear smeared in the reconstructions. Therefore, the rods

79 were processed and reconstructed independently, yielding a resolution of $2.1 \AA$. The rods cannot be

80 further sorted into distinct classes, suggesting that all rods within one complex are identical (Extended

81 Data Fig. 2c).

82 The PBS core consists of three cylinders, a top cylinder (T) stacked on top of two basal cylinders (B1,

83 B2) (Fig. 1, Extended Data Fig. 4). Each of the two B cylinders have one rod attached while four rods

84 are attached to the $\mathrm{T}$ cylinder. The core consists of 80 polypeptide chains and 72 phycocyanobilins

85 (PCB), and each rod contains 40 protein subunits and 54 PCBs, adding up to a total of 320 proteins

86 and 396 bilin molecules that amount to a molecular weight of 6.2 MDa. Extended Data Figure 4 and

87 Extended Data Table 1 provide an inventory of the subunits, their component protein family (pfam)

88 domains and functional characteristics. 
bioRxiv preprint doi: https://doi org/10.1101/2021.11.15.468712; this version posted November $15,2021$. The copyright holder for this preprint (which was not certified by peer review) is the author/funder, who has granted bioRxiv a license to display the preprint in perpetuity. It is made available under aCC-BY-NC-ND 4.0 International license.

Structures of the Cyanobacterial Phycobilisome
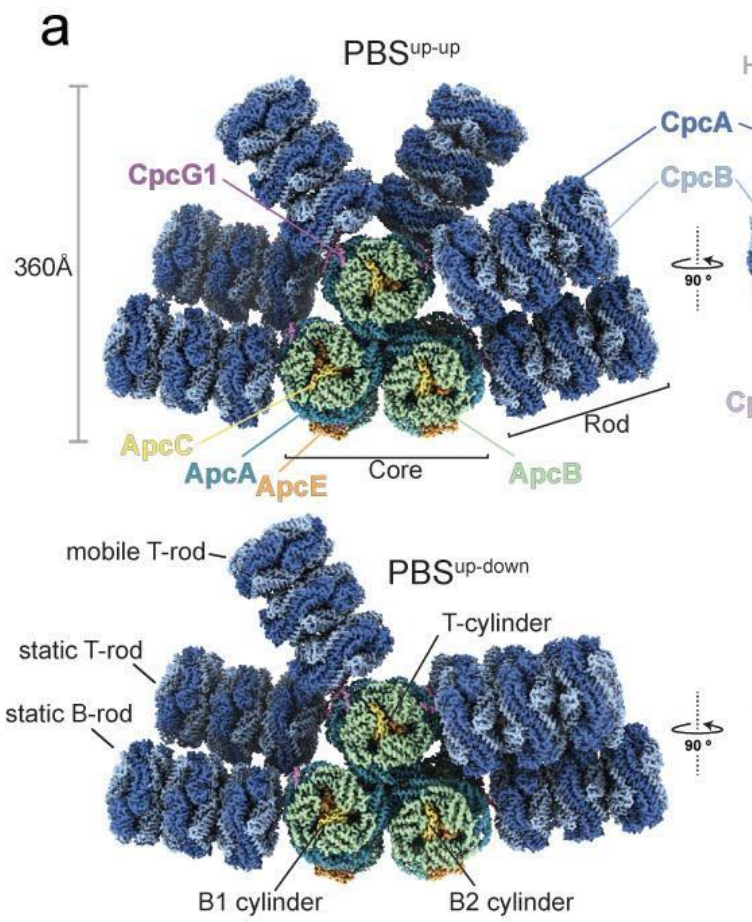

PBS down-down

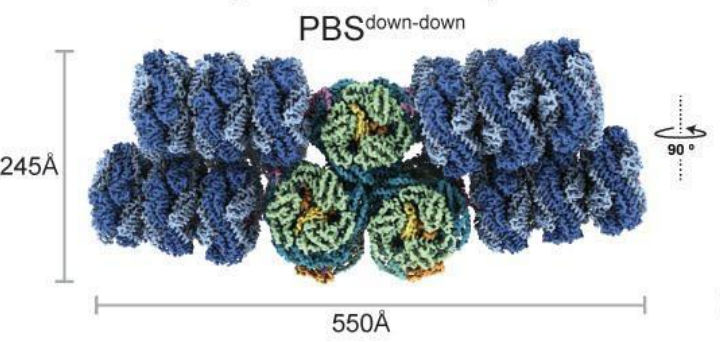

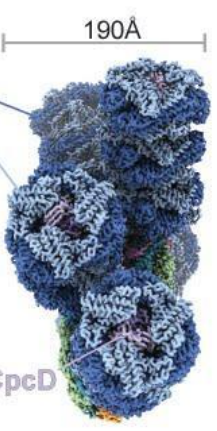
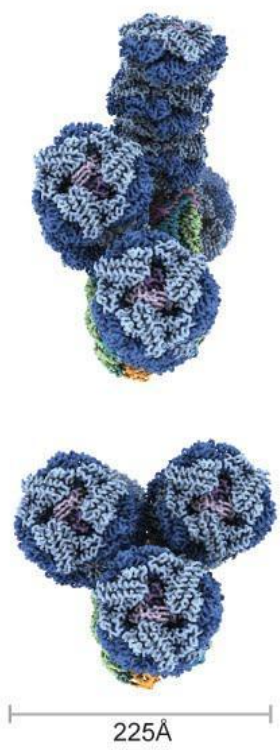
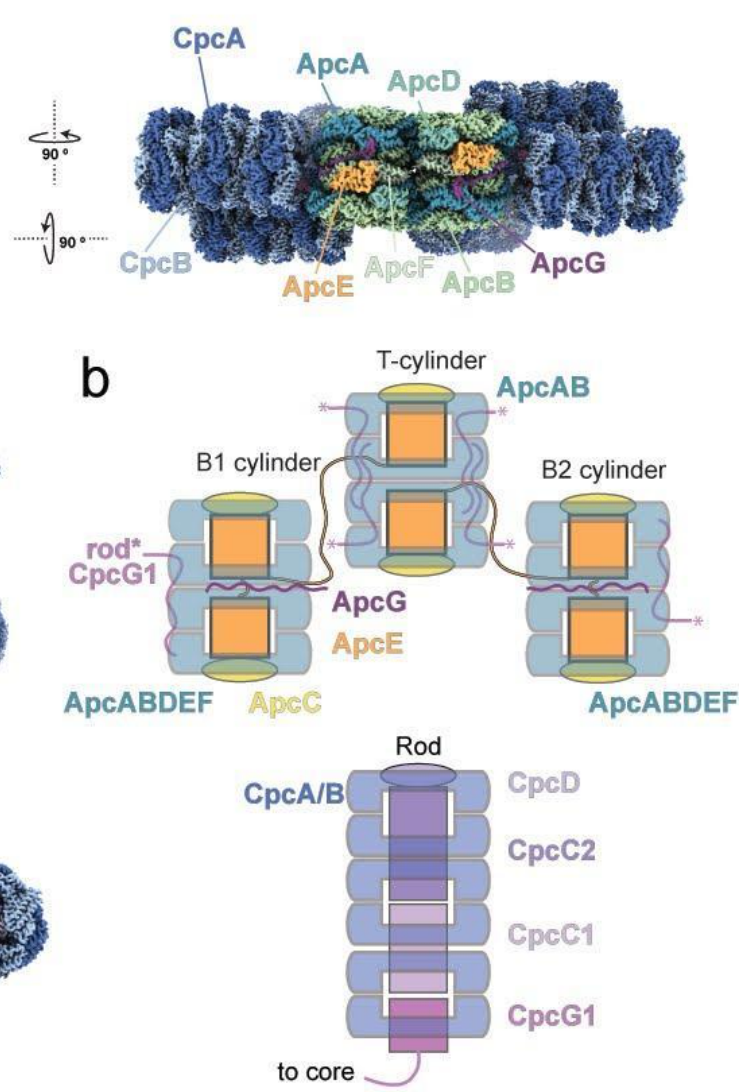

Figure 1: Structural characterization of the phycobilisome from Synechocystis PCC 6803. a, Composite cryo-EM density

maps representing the three PBS conformations: Up-up (top), up-down (middle), down-down (bottom). Individual maps and resolution for the three conformations and the rod can be found in Extended Data Fig. 2. b. Schematic overview of PBS connectivity and subunit arrangement of the core (top) and the rods (bottom).

94 In contrast to earlier studies, our structures include three different, major rod conformations; two have not been visualized before. They are distinguished by alternate positioning of two of the four T rods (hence referred to as mobile T rods, as opposed to the static T rods). In the 'up-up' conformation, both mobile rods are tilted upwards, corresponding to the canonical hemidiscoidal PBS. Two previously unreported conformers were also present: the 'up-down' conformation, where one of the mobile rods moved downwards to assume a position parallel to the other rods and the 'down-down' conformation, in which all the $\mathrm{T}$ cylinder rods are in a down position, reducing the 'height' of the complex by more than $100 \AA$ and giving the PBS a more compact profile (Fig. 1a). 
bioRxiv preprint doi: https://doi org/10.1101/2021.11 15.468712: this version posted November 15,2021 . The copyright holder for this

preprint (which was not certified by peer review) is the author/funder, who has granted bioRxiv a license to display the preprint in perpetuity. It is made available under aCC-BY-NC-ND 4.0 International license.

Structures of the Cyanobacterial Phycobilisome

\section{Linker architecture and identification of a new linker component, ApcG}

103 Both the core and the rods contain linker proteins in their central cavities that provide scaffolding and 104 organize the arrangement of the Apc and Cpc subunits, thereby ensuring the proper orientation and 105 spacing of the pigments (Fig. 1b, 2a). Central to the organization are two copies of ApcE (Fig. 2a, b, 106 Extended Data Fig. 5a) which form the major scaffold for the core by connecting the bottom with the 107 top cylinders ${ }^{15-17}$. The PB loop (residues $87-129$ ) is disordered and could not be modeled, but all other 108 ApcE domains are well resolved. The three cylinders are 'capped' by six copies of ApcC that interact 109 with ApcE (Fig. 2a, Extended Data Fig. 5b). 
bioRxiv preprint doi: https://doi org/10.1101/2021.11 15,468712; this version posted November $15,2021$. The copyright holder for this preprint (which was not certified by peer review) is the author/funder, who has granted bioRxiv a license to display the preprint in perpetuity. It is made available under aCC-BY-NC-ND 4.0 International license.

Structures of the Cyanobacterial Phycobilisome
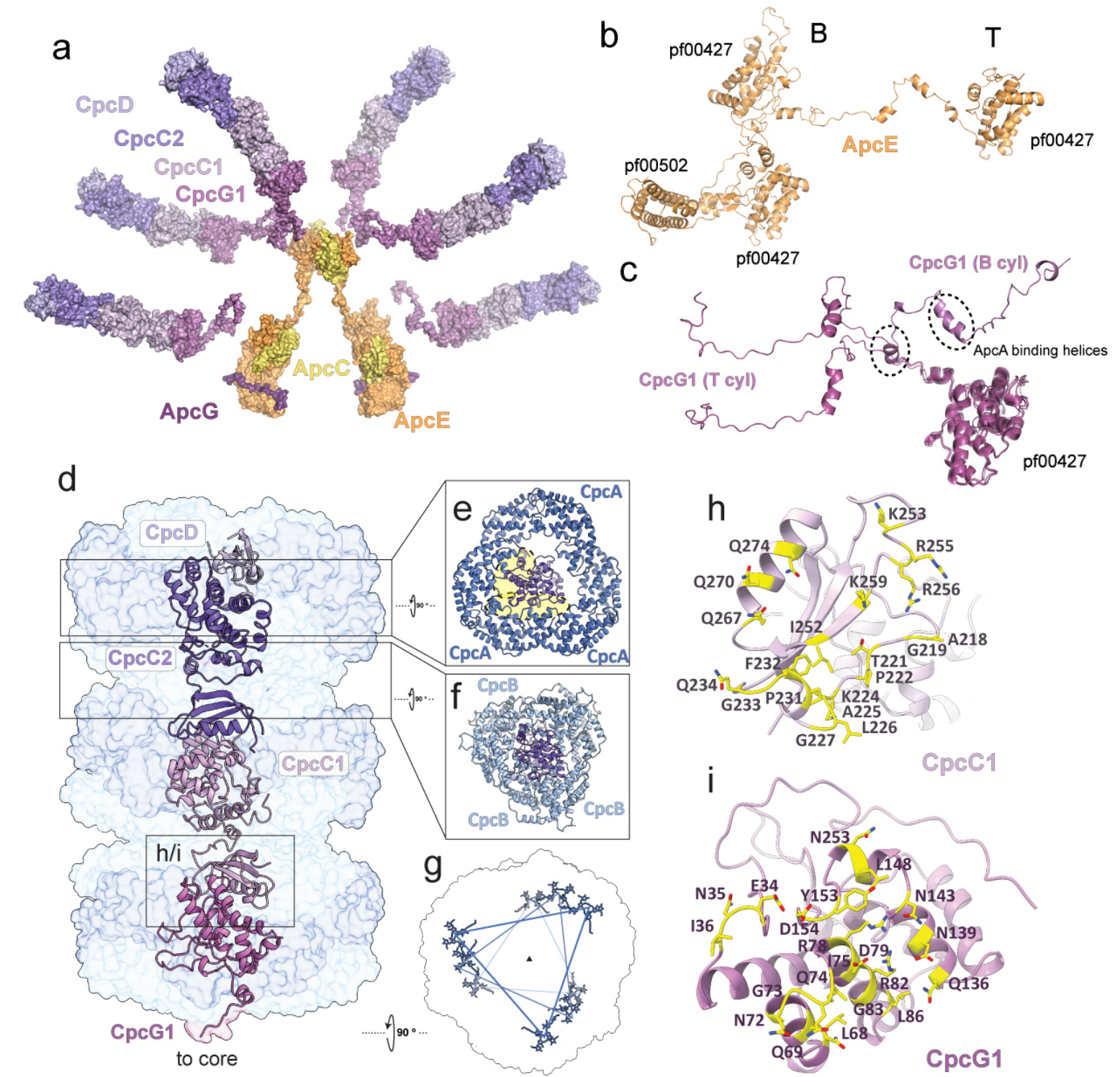

Figure 2: Core and rod linkers. a, Surface representation of the linker skeleton of the entire PBS. b, ApcE with its

112 constituent domains pf00502 and pf00427. c, CpcG1 linker conformations from top (T) and bottom (B) cylinders in the up-

113 up conformation. d, Linker proteins within a rod. CpcC1/2 contain a pf00427 and pf01383 domain, CpcD only a pf01383

114 domain $\boldsymbol{e}$, Interface of $\mathrm{CpcC2}$ with $\mathrm{CpcA}$ proteins. Predominant contacts between the linker and CpcA proteins are

115 highlighted in yellow. $\mathrm{f}, \mathrm{CpcC1/2}$ interact more closely with $C p c B$ than $C p c A$. $\mathrm{g}$, Bilin arrangement within the rod showing

116 spiraling pattern. $\boldsymbol{h}$ and $\boldsymbol{i}, \mathrm{CpcCl}$ and $\mathrm{CpcG1}$ amino acids interfaces along the long axis of the rod highlighted in yellow.

117 In the rods, there are four linker proteins (Fig. 2 a, d). CpcG1 is located at the core-proximal side. Its

11860 residue C-terminal extension attaches it to the PBS core (Figure $2 \mathrm{c}, \mathrm{d}$, Extended Data Fig. 5c). The

119 homologues $\mathrm{CpcC} 1$ and $\mathrm{CpcC} 2$ form the bulk of the interior of the rods (Fig. 2d, Extended Data Fig. 
bioRxiv preprint doi: https://doi.org/10.1101/2021.11.15.468712; this version posted November 15, 2021. The copyright holder for this preprint (which was not certified by peer review) is the author/funder, who has granted bioRxiv a license to display the preprint in perpetuity. It is made available under aCC-BY-NC-ND 4.0 International license.

Structures of the Cyanobacterial Phycobilisome

$1205 \mathrm{~d}$ ). The interdomain linker of $\mathrm{CpcC} 1$ is 15 residues longer than in $\mathrm{CpcC} 2$, allowing for a $70^{\circ}$ rotation

121 of the pf01383 domain of $\mathrm{CpcC} 1$ compared to $\mathrm{CpcC} 2$ (Extended Data Fig. 5d). This results in an 122 apparent $10^{\circ}$ rotation between each CpcA/B hexamer (Fig. $2 \mathrm{~g}$ ). Even though all linker proteins within 123 the rod employ the same two domains to connect to one another, differences in the binding interface 124 of each domain pair define a unique architecture for the correct assembly of the entire rod (Fig. 2 h, i, 125 Extended Data Fig. 5 e-g).

127 A previously unknown linker protein (sll1873) was discovered in the cryo-EM density and identified 128 by mass spectrometry (Fig. 3a, Extended Data Table 2). We denote it ApcG or $\mathrm{L}_{\mathrm{C} 10}$ in continuation of 129 the established nomenclature. It is found only on the bottom two cylinders extending toward the 130 membrane-facing side. An HMM search reveals that homologues are found in about $80 \%$ of 131 cyanobacterial genomes. ApcG contains two conserved sequence motifs including a short helix that 132 binds in a groove on ApcA like CpcG1 (Fig. 3b, Extended Data Fig. 5b). The highly conserved residue 133 R100 of ApcG directly contacts the PCB of ApcA in the bottom cylinder, suggesting that it may 134 finetune its spectroscopic properties. It has previously been suggested that the PBS interacts with lipid 135 head groups ${ }^{31}$; ApcG could mediate this interaction through its positively charged linker region (Fig. $1363 \mathrm{~b})$. Given its location close to the terminal emitters and the membrane, we propose that ApcG likely 137 plays a key role in PBS localization and energy transfer to PSII.

\section{Terminal emitters}

139 At the membrane facing side of the PBS, the terminal chromophores of ApcD and ApcE are 140 responsible for transferring the absorbed energy to the reaction centers (Fig. 3c, Extended Data Fig. 141 4). ApcF has been shown to play a crucial role in energy migration to ApcE and also to impact state 142 transitions ${ }^{32,33}$. The center-to-center distance between the PCBs of ApcE and ApcF is $23 \AA$, and $35 \AA$ 143 between the PCBs of ApcD and ApcF (Fig. 3d). While these distances fall well within the range of 
bioRxiv preprint doi: https://doi org/10.1101/2021.11.15.468712; this version posted November $15,2021$. The copyright holder for this preprint (which was not certified by peer review) is the author/funder, who has granted bioRxiv a license to display the preprint in perpetuity. It is made available under aCC-BY-NC-ND 4.0 International license.

Structures of the Cyanobacterial Phycobilisome

other PCB distances, their local environments are likely responsible for the observed shift in

145 fluorescence emission of ApcE and ApcF to $680 \mathrm{~nm}$ (as opposed to $660 \mathrm{~nm}$ for ApcA). Rigid body

146 docking of our structure into a negative stain map of the related Anabaena sp. PBS bound to PSII ${ }^{25}$

147 suggests that the closest inter-pigment distance between the PBS and PSII might be as large as 50 $\AA$

148 (Fig. 3e). The requirement to spectroscopically bridge such a distance might be one of the drivers for

149 the diversification of ApcD, E and F around the terminal chromophores of the PBS and leading to their 150 unique properties.

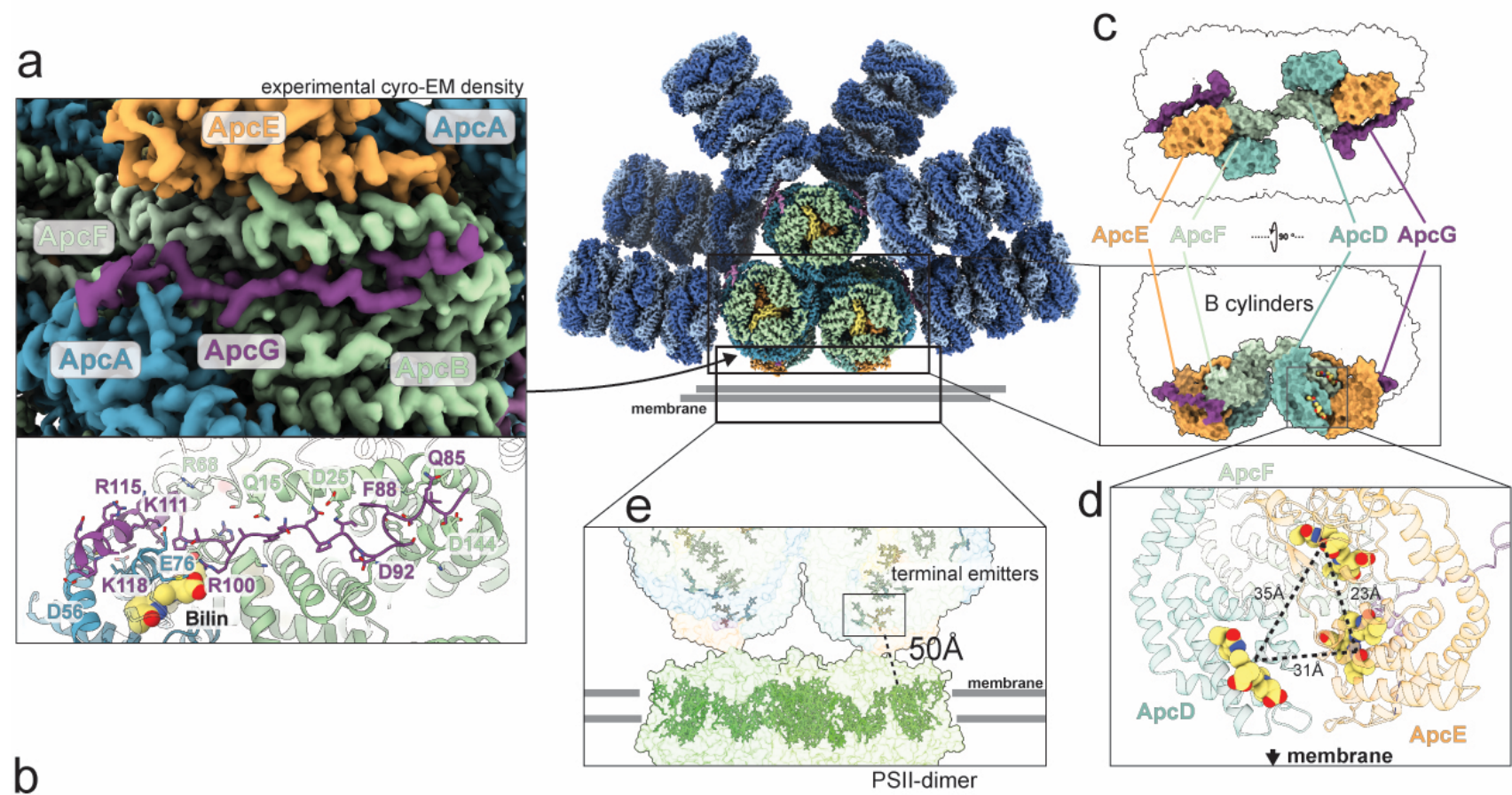



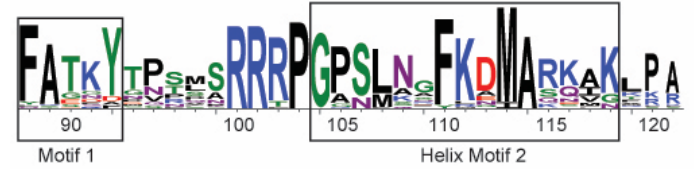

152 Figure 3: A newly identified linker ApcG and Terminal emitters. a, Position and interaction of ApcG within the PBS. b,

153 Sequence conservation logo of ApcG homologs. The numbers refer to residue positions in Synechocystis PCC 6803 ApcG.

154 ApcG contains three conserved sequence motifs including a short helix that binds in a central groove of ApcA like CpcG1.

$155 \boldsymbol{c}$, Position and orientation of the subunits ApcD, ApcE, ApcF and ApcG within the core of the PBS. Only the 
bioRxiv preprint doi: https://doi org/10.1101/2021.11 15,468712; this version posted November $15,2021$. The copyright holder for this preprint (which was not certified by peer review) is the author/funder, who has granted bioRxiv a license to display the preprint in perpetuity. It is made available under aCC-BY-NC-ND 4.0 International license.

Structures of the Cyanobacterial Phycobilisome

phycobiliprotein domain of ApcE is rendered. d, Orientation and distances of the PCBs of ApcD, ApcE and ApcF.e, Rigid

body modelling of our PBS core structure onto PSII, using EMDB 2822 as a reference.

\section{Core-rod linker architecture and conformational switching}

Rod attachment is mediated by CpcG1, which protrudes from the central cavity of each rod and latches

onto the surface of the core cylinders. The PBS core accommodates the CpcG1 linkers through a
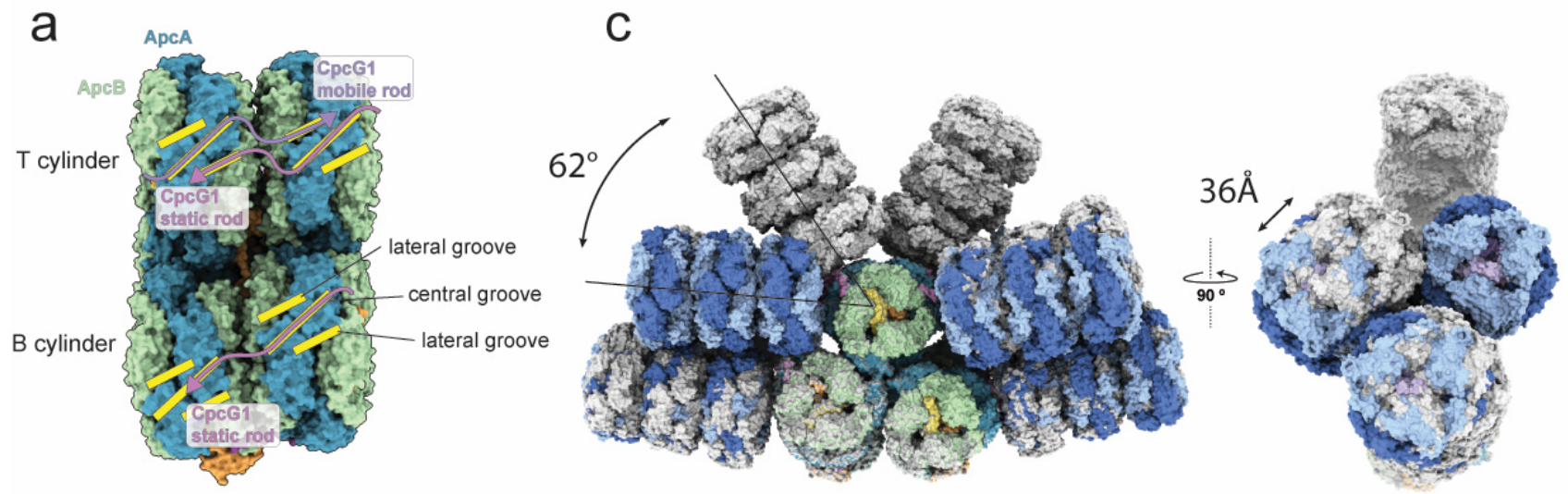

b
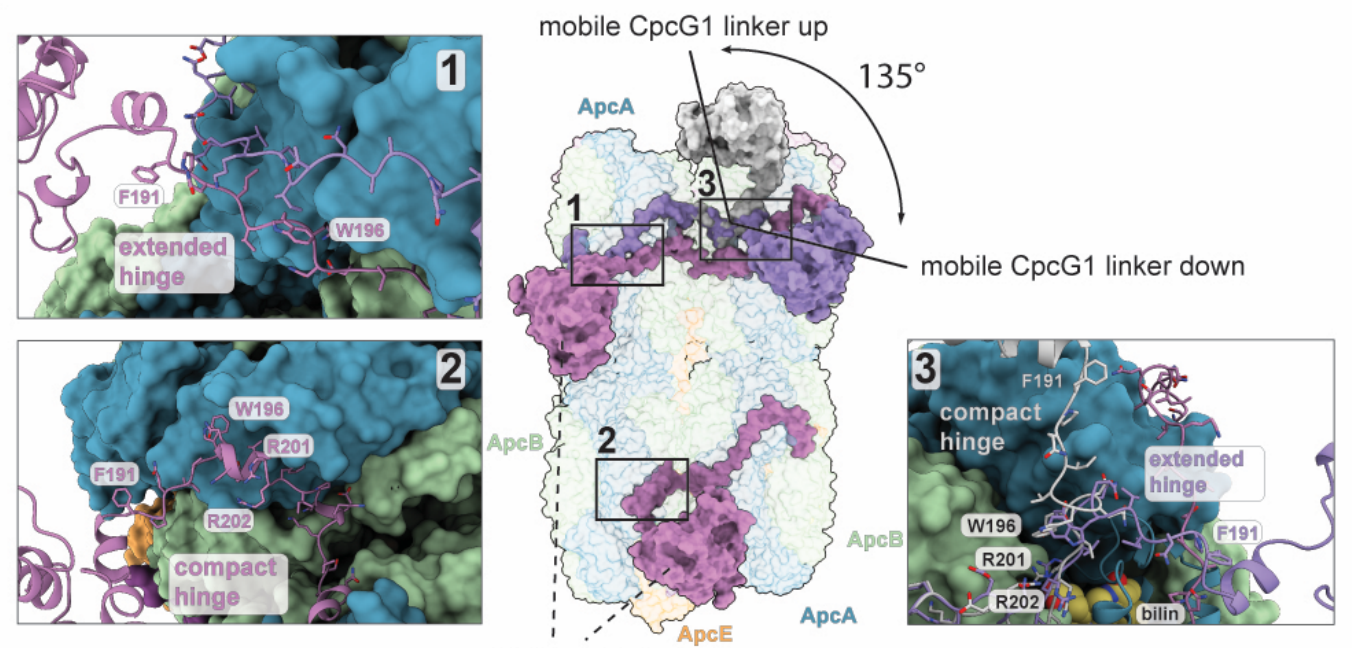

static CpcG1 linker

Figure 4: Structural basis for conformational switching. a Side view of the PBS core omitting the rods showing the groove

network that organizes CpcG1 linker attachment. b, Same side view of the PBS core emphasizing the CpcG1 position. 
bioRxiv preprint doi: https://doi.org/10.1101/2021.11.15.468712; this version posted November 15, 2021. The copyright holder for this preprint (which was not certified by peer review) is the author/funder, who has granted bioRxiv a license to display the preprint in perpetuity. It is made available under aCC-BY-NC-ND 4.0 International license.

Structures of the Cyanobacterial Phycobilisome

mobile rod is a PCB molecule that is contacted by R201 of CpcG1. c, Superimposition of PBS $S^{\text {down-down }}$ (in color) and PBS ${ }^{\text {up }}$ up (light grey) showing the large conformational differences between the two.

The conformations of the CpcG1 linkers correlate within the three rod (Fig. 4b). When comparing the linkers of the top and bottom static rods it is apparent that the linker can adopt one of two different conformations: extended or compact. In the compact state, a conserved six amino acid region (W196R201), which we define as the 'hinge' forms a small coil or helix that changes the local geometry of the linker relative to the extended state (Fig. 2c, 4b). Of the two static rods, the hinge of the upper rod adopts the extended conformation, while the hinge of the lower rod is in the compact conformation (Fig 4b). As a consequence of this conformational difference, the globular domain of the lower CpcG1 is rotated with respect to the globular domain of the upper CpcG1. This rotation is locked in place only for the static rods, the mobile rod however can toggle between these two states which are determined by the conformation of the hinge. Superposing the position of CpcG1 of the mobile rod in its 'down' conformation with its own 'up' conformation reveals that the movement of the mobile rod between 'down' and 'up' corresponds to the conformational change of the linker between compact and extended. As a result, the globular CpcG1 domain along with the entire rod rotates by $135^{\circ}$ around its long axis when swinging from 'down' to 'up' (Fig. 4b). Most importantly, this switch is accommodated by a $62^{\circ}$ upwards swing of the entire rod, which is the most striking difference between the 'down' and 'up' conformations (Fig. 4c). A similar conformational change from the mobile rod to the static rods is precluded because it would result in a clash of the static rods. The bottom static rod would swing upwards while the upper static rod would swing downwards. This mutual blockade alone is sufficient to explain the static nature of these two rods.

The mobile rod is held in place in its 'down' position through interactions with its static rod neighbor. Two $\operatorname{Cpc}(\alpha \beta)_{6}$ hexamers proximal to the PBS core interact through a salt bridge that is formed between R150 of one of the CpcB's in the mobile rod and E131 of one of the CpcA's in the static rod (Extended Data Fig. 6b). 
bioRxiv preprint doi: https://doi org/10.1101/2021.11.15.468712; this version posted November 15,2021 . The copyright holder for this preprint (which was not certified by peer review) is the author/funder, who has granted bioRxiv a license to display the preprint in perpetuity. It is made available under aCC-BY-NC-ND 4.0 International license.

Structures of the Cyanobacterial Phycobilisome

193 The superposition of 'down' and 'up' conformations also reveals that the upper static rod experiences 194 a $36 \AA$ lateral displacement when the mobile rod is down but relaxes into its central position once the 195 mobile rod swings upwards (Fig. 4c). Once in the central position, the static rod obstructs the 196 downward movement of the mobile rod and stabilizes this conformation. Hence, in every case the 197 mobile rod needs to overcome an energy barrier to move either direction.

\section{Energy transfer pathways in the different PBS conformations}

199 To better understand the impact of the different conformations we computationally modeled the energy 200 transfer within the phycobilisome based on our structural data. We assume energy transfer in the limit 201 of Förster theory using a dipole-dipole approximation for inter-pigment couplings. The map of energy 202 transfer rates for the PBS in the up-up conformation is shown in Fig. 5, demonstrating a robust system, 203 in which excitation of essentially any pigment directs the excitation quickly to the terminal emitters. 204 It also shows that the bottleneck is the rod-to-core energy transfer, as suggested by global fitting 205 models of time-resolved fluorescence data ${ }^{34}$. Energy transfer between the pigments in the core, both 206 within and between the cylinders, is more efficient than rod-to-core transfer, contradicting the global 207 fitting models that predict slow inter-cylinder transfer ${ }^{35}$, but the overall flow of energy through the whole PBS obtained from our model matches the experimental data well (Extended Data Fig. 7a, b). 
a
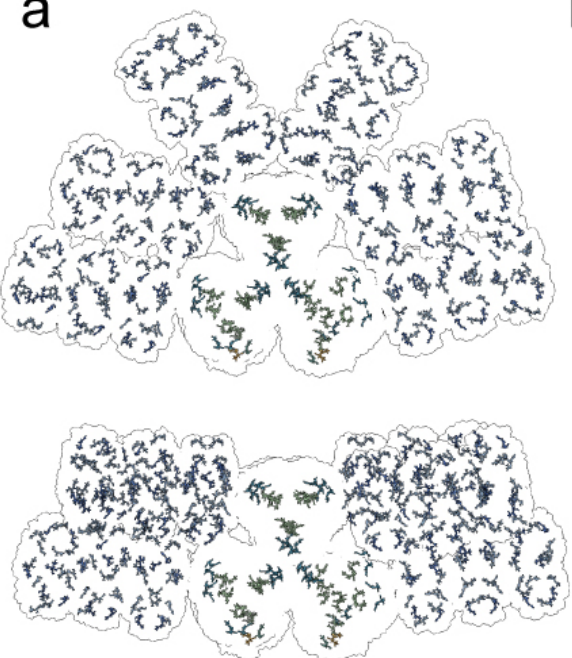

b
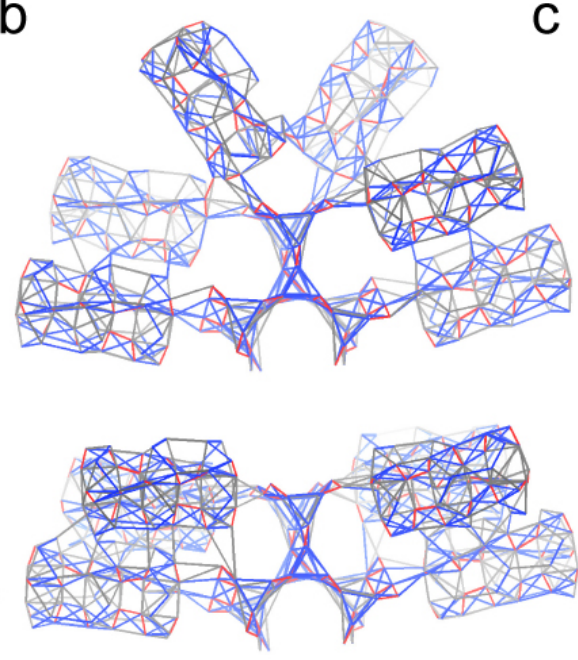

C

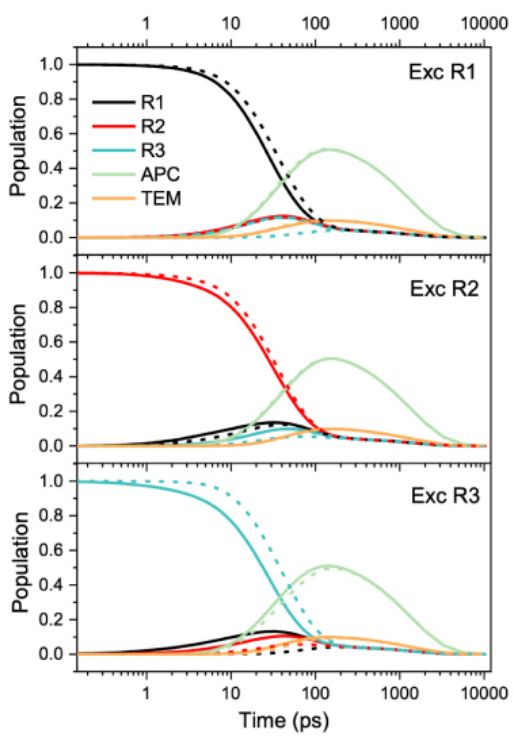

Figure 5: Energy flow through the PBS. a, Pigment distribution within $P B S^{u p-u p}$ (top) and PBS $S^{\text {down-down }}$ (bottom). b, Maps

of individual inter-pigment energy transfer rates of $P B S^{u p-u p}$ (top) and $P B S^{\text {down-down }}$ (bottom). The color bars correspond to

rates faster than 1 ps (red), in the 1-10 ps range (blue) and in 10-20 ps range (grey). Inter-pigment rates slower than 20

ps are omitted. $\boldsymbol{c}$, Energy flow through down-down (solid) and up-up (dashed) PBS configurations. The excitation is placed

either on the mobile rod R1 (top), middle rod R2 (middle) or bottom rod R3 (bottom). The curves monitor the evolution of

The individual rate constants shown in the map are used to calculate how long the excitation resides

this approach, we also investigated the energy transfer through both the up-up and the down-down

PBS conformations by placing the excitation to the most distant disc of the respective rods (Fig. 5c).

220 For both conformations, the excitation reaches the APC core in less than 100 ps, in agreement with

221 experimental data (see Extended Data Fig. 7a, b). Moving the mobile rod to the down position (solid

222 lines in Fig. 5c) facilitates inter-rod energy transfer, as the more packed conformation increases the

223 probability of energy transfer between bilins from different rods. Excitation of the mobile rod in down-

224 down conformation leads to about $10 \%$ population of the lowest rod, while for the up-up conformation

225 the population of this rod is essentially zero (Fig. 5c). The same effect occurs for excitation of the 
bioRxiv preprint doi: https://doi.org/10.1101/2021.11.15.468712; this version posted November 15, 2021. The copyright holder for this preprint (which was not certified by peer review) is the author/funder, who has granted bioRxiv a license to display the preprint in perpetuity. It is made available under aCC-BY-NC-ND 4.0 International license.

Structures of the Cyanobacterial Phycobilisome

227 non-negligible population is found at the other rods in the down-down PBS (Fig. 5c). Thus, the more

228 compact down-down conformation allows for more pathways to reach the core, slightly increasing the 229 overall trapping efficiency. On the other hand, the fact that significant movement of the mobile rod 230 keeps the overall flow of energy through the system virtually unchanged points to robustness of PBS 231 with respect to light-harvesting capacity. The robustness of PBS is further underscored by comparison 232 with the red algal PBS, which shows that the overall dynamics are comparable ${ }^{15,16,36}$.

233 We note that two PBS configurations differing by their fluorescence spectra have been identified by 234 single molecule spectroscopy ${ }^{37}$. It is thus tempting to associate the up-up and down-down 235 conformations with those two species. Here, however, the structures of up-up and down-down 236 conformations do not yet reveal any influence on the structure of the PBS core that is needed to change 237 the fluorescence of terminal emitters. Thus, the relation of the two species identified by different 238 methods remains to be defined.

\section{Importance of conformational switching for light harvesting}

240 The quality of our structural data and the various proportions of the three PBS conformations suggests

241 that we have captured previously unknown conformations of the cyanobacterial antenna. Why have

242 the different rod conformations not been described before? In retrospect, it becomes clear that during 243 earlier attempts to visualize the cyanobacterial PBS different conformation were probably confounded 244 with general flexibility ${ }^{22}$ or likely disregarded as damaged particles ${ }^{38}$. Other methods to determine the 245 structural arrangement of the rods like crosslink-MS are not suited to distinguish between inter and 246 intra-rod contacts and therefore are likewise blind to the conformations we identified ${ }^{29,39}$. Because the 247 static rods already display two different hinge conformations, it is unlikely that the rod movement is 248 an artifact from sample preparation or imaging. The observed movement is directional and 249 quantifiable, hallmarks of true biologically relevant conformational changes. It is tempting to assume 250 that the mechanistic cause for the rod movement is coupled to the transfer of excitation energy through 
bioRxiv preprint doi: https://doi.org/10.1101/2021.11.15.468712; this version posted November 15, 2021. The copyright holder for this preprint (which was not certified by peer review) is the author/funder, who has granted bioRxiv a license to display the preprint in perpetuity. It is made available under aCC-BY-NC-ND 4.0 International license.

Structures of the Cyanobacterial Phycobilisome

251 the PBS. Pigment molecules can be found near several residues critical for rod movement (Fig. 3d,

252 Extended Fig. 6b), but further studies are now needed to explore whether any of the pigments within

253 the PBS can indeed trigger a conformational change and dictate rod position. The newly described

254 PBS architectures suggests a regulation of light harvesting at the level of supramolecular organization

255 in the thylakoid membrane that is somehow regulated by rod movement.

256 We propose two scenarios for placing our structures in that context. PBS arrays efficiently pack light

257 harvesting pigments on the surface of the thylakoid membrane and thus increase the overall photon

258 absorption cross-section of a cell. Additionally, they create redundancy of light harvesting and

259 photochemical energy conversion at the reaction centers and can thus alleviate energetic losses due to

260 damaged PSII. Using the published structure of an array as a model ${ }^{40}$, we found that only the 'up-up'

261 state of the PBS could be fitted into the array (Extended Data Fig. 7c). Modeling of the energetics of

262 our structure in arrays indicates that lateral energy transfer between PBSs within an array is possible,

263 mainly between adjacent PBS cores.

265 Under certain conditions, PBS arrays might need to be dismantled to rebalance PSII versus PSI

266 excitation pressure. Given that the down-down and down-up PBS conformations cannot be fitted into

267 arrays, (Extended Data Fig. 7d, e), a conformational change in one PBS unit could therefore help to

268 break up such arrays by acting as a terminator or interrupter of PBS array formation.

269 The second scenario in which PBS conformation may regulate the balance between light harvesting

270 and photoprotection is coupled with the activity of the photoreceptor OCP. OCP quenches the

271 excitation energy by converting it to vibrational energy. Activated OCP binds to the lateral side of the

272 PBS core in the space between the rods ${ }^{41}$. However, the binding site is completely blocked when the

273 mobile rod is in the 'down' position. Therefore, the mobile rod controls access of OCP to the PBS core

274 and determines whether the PBS can be quenched. 
bioRxiv preprint doi: https://doi org/10.1101/2021.11.15.468712; this version posted November 15,2021 . The copyright holder for this preprint (which was not certified by peer review) is the author/funder, who has granted bioRxiv a license to display the preprint in perpetuity. It is made available under aCC-BY-NC-ND 4.0 International license.

Structures of the Cyanobacterial Phycobilisome

276 Having more than one mechanism could be a means for the cell to fine tune its light harvesting

277 efficiency to adjust to altered metabolic and cellular requirements. Moreover, these scenarios are not

278 mutually exclusive and could work concurrently, but on different time scales, to adjust light-harvesting

279 in response to environmental changes. The OCP binding site is still accessible in PBS arrays ${ }^{41}$, and 280 thus PBS arrays are readily available for OCP induced excitation energy quenching upon rapid changes

281 in the environment. Supramolecular rearrangements of the photosynthetic machinery can then take

282 place to rebalance light harvesting, which might involve rod movement and array dispersion. Several

283 studies have revealed that excitation energy harvested at the PBS can be transferred to PSI ${ }^{39}$. Given

284 that PSI does not require excitation energy quenching at the light-harvesting system, it can be 285 hypothesized that the down-down position obscuring the OCP binding site might be involved mainly 286 in transferring its harvested energy to PSI. In fact, in such a scenario, OCP induced quenching would 287 be counterproductive.

289 Here, we present the first high-resolution structures of cyanobacterial phycobilisomes, revealing an 290 unexpected variety of conformational states that help to collect and deliver light energy to 291 photosynthetic reaction centers. Further analysis of these structures will inform future experiments that 292 will help us to understand and harness the power of these large light harvesting machines. 
bioRxiv preprint doi: https://doi org/10.1101/2021.11.15.468712; this version posted November 15, 2021. The copyright holder for this preprint (which was not certified by peer review) is the author/funder, who has granted bioRxiv a license to display the preprint in perpetuity. It is made available under aCC-BY-NC-ND 4.0 International license.

Structures of the Cyanobacterial Phycobilisome

Methods

\section{Preparation of the Synechocystis PCC 6803 Phycobilisome}

303 Synechocystis PCC 6803 were grown photoautotrophically in a BG11 medium. Cells were kept in a 304 rotary shaker $(100 \mathrm{rpm})$ at $30^{\circ} \mathrm{C}$, under $3 \% \mathrm{CO}_{2}$ enrichment, illuminated by white fluorescent lamps 305 with a total intensity of about $30 \mu \mathrm{mol}$ photons $\mathrm{m}^{-2} \mathrm{~s}^{-1}$. The protocol used for PBS isolation was 306 based on ${ }^{42,43}$. The cells were collected at 8,000 rpm, $10 \mathrm{~min}$ at room temperature. The pellet was 307 resuspended in $10 \mathrm{~mL}$ of PBS isolation buffer $(0.75 \mathrm{M}$ potassium phosphate buffer $\mathrm{pH} 7.5,1 \mathrm{mM}$ 308 EDTA, $0.5 \mathrm{mM}$ PMSF) per $2 \mathrm{~g}$ of fresh weight of cells. Then, the cells were washed twice by 309 centrifugation at 30,000 $\mathrm{g}$ during $15 \mathrm{~min}$. The cells were broken through French Press at 1,000 psi 310 three times. The supernatant was incubated in the presence of $2 \%(\mathrm{v} / \mathrm{v})$ Triton X-100 under dim 311 stirring, at $23^{\circ} \mathrm{C}, 15-20 \mathrm{~min}$. The cell debris and the aggregates were removed by ultracentrifugation 312 at $20,000 \mathrm{rpm}$ (Ti-70 rotor) for $20 \mathrm{~min}$ at room temperature. The dark blue supernatant was directly 313 loaded onto a discontinuous sucrose gradient $(0.5,0.75,1$, and $1.5 \mathrm{M}$ sucrose layers in $0.75 \mathrm{M}$ 314 potassium phosphate buffer, $\mathrm{pH} 7.5$ ), and spun at $150,000 \mathrm{~g}, 23^{\circ} \mathrm{C}$, for $16 \mathrm{~h}$ using a SW28 rotor. The 315 intact PBS was recovered from the $0.75-1 \mathrm{M}$ interface of the sucrose gradient. The PBS were buffer 316 exchanged into $0.75 \mathrm{M}$ potassium phosphate buffer $\mathrm{pH} 7.5$ using Amicon (30 kDa). The samples were 317 kept at room temperature for further use.

\section{Protein separation}

319 The isolated PBS samples were concentrated by precipitation with $20 \%(\mathrm{v} / \mathrm{v})$ trichloroacetic acid prior 320 to loading on a sodium dodecyl sulfate-polyacrylamide gel electrophoresis (SDS-PAGE) 5-20\% 321 gradient gel. The gels were run for $25 \mathrm{~min}$ at $240 \mathrm{~V}$ and were stained by Coomassie Brilliant Blue. 322 The protein composition of the SDS-PAGE confirms the presence of all PBS subunits (Extended Data 323 Tables 1, 2). 
bioRxiv preprint doi: https://doi org/10.1101/2021.11.15.468712; this version posted November 15, 2021. The copyright holder for this preprint (which was not certified by peer review) is the author/funder, who has granted bioRxiv a license to display the preprint in perpetuity. It is made available under aCC-BY-NC-ND 4.0 International license.

Structures of the Cyanobacterial Phycobilisome

Absorption and fluorescence spectrum measurement

325 PBS ultraviolet-visible (UV-vis) absorption spectra were collected with a Cary 60 spectrophotometer 326 (Agilent). The fluorescence emission spectra of the PBS were recorded at room temperature from 600 327 to $800 \mathrm{~nm}$ in a fluorimeter (TECAN Spark 20M multimode microplate reader) with an excitation 328 wavelength of $580 \mathrm{~nm}$.

\section{PBS biotinylation}

330 The ChromaLink ${ }^{\mathrm{TM}}$ Biotin Labeling reagent, purchased from Solulink (see $331 \mathrm{https}: / /$ vectorlabs.com/chromalink-biotin-antibody-labeling-kit.html), was used as it incorporates a 332 chromophore as part of the linker. $120 \mu \mathrm{l}$ of the PBS in $0.75 \mathrm{M}$ potassium-phosphate $\mathrm{pH} 7.5$ was buffer 333 exchanged with the 1X Modification buffer(10X Modification buffer- $100 \mathrm{mM}$ sodium phosphate and $334150 \mathrm{mM}$ sodium chloride $\mathrm{pH} 8.0$-diluted in $0.75 \mathrm{M}$ potassium-phosphate $\mathrm{pH}$ 8.0). Then, the sample 335 amount was quantified using an absorbance spectrum and using the values at 280, 354 and $620 \mathrm{~nm}$ to 336 calculate the amount of biotin to add to the reaction. The samples were then incubated for $120 \mathrm{~min}$ at 337 room temperature. The sample was buffer exchanged back into $100 \mu$ of $0.75 \mathrm{M}$ potassium-phosphate 338 pH 7.5 using a Zeba Spin Desalt 7 kDa MWCO column, Thermo Scientific). UV-vis spectra were 339 measured from 230-800 $\mathrm{nm}$ for biotinylated protein samples using a Tecan Safire microplate reader. 340 Using the absorbance values at 280, 354 and $620 \mathrm{~nm}$, and the molar extinction coefficients, the average 341 number of biotin molecules covalently attached per PBS were calculated to be about 1 . Fluorescence 342 emission spectra were used to confirm functional energy transfer in the isolated PBS before and after 343 biotinylation (Extended Data Fig. 1d).

\section{Cryo-EM sample preparation from purified PBS}


bioRxiv preprint doi: https://doi org/10.1101/2021.11.15.468712; this version posted November 15,2021 . The copyright holder for this preprint (which was not certified by peer review) is the author/funder, who has granted bioRxiv a license to display the preprint in perpetuity. It is made available under aCC-BY-NC-ND 4.0 International license.

Structures of the Cyanobacterial Phycobilisome

345 For sample preparation we used Quantifoil Au 300 mesh 2/1 grids covered with a home-made 346 streptavidin monolayer, which were manufactured as described previously ${ }^{30}$. To apply the sample, 347 grids were first rehydrated in buffer A (375 mM potassium phosphate, $\mathrm{pH} 7.5)$ and then blotted dry 348 with filter paper. $4 \mu \mathrm{l}$ of PBS sample at $5.3 \mathrm{mg} / \mathrm{ml}$ in buffer $\mathrm{B}(750 \mathrm{mM}$ potassium phosphate, $\mathrm{pH} 7.5)$ 349 were added to the grid and then incubated on the bench for 60 seconds. Grids were washed on two 10 $350 \mu$ drops of buffer C (375 mM potassium phosphate, $\mathrm{pH} 7.5,3 \% \mathrm{w} / \mathrm{v}$ trehalose, $0.01 \% \mathrm{v} / \mathrm{v} \mathrm{NP} 40,0.05 \%$ $351 \mathrm{w} / \mathrm{v}$ beta-octylglucoside) before being carefully wicked with Whatman filter paper. $1 \mu \mathrm{l}$ of buffer C 352 was added quickly, and the grid lifted into a FEI Mark IV Vitrobot. The grid was then manually blotted 353 for $2-3 \mathrm{~s}$ at $18^{\circ} \mathrm{C}$ and $100 \%$ humidity before plunging into a liquid ethane-propane (3:1) mix $^{44}$. During 354 the process, the PBS was exposed to ambient light for a total of approximately 2-3 min between 355 pipetting and vitrification.

\section{Cryo-EM data collection PBS}

357 For initial assessment of the sample, grids were loaded onto a Talos Arctica microscope (Thermo 358 Fisher Scientific) equipped with a Gatan K3 direct electron detector and operating at $200 \mathrm{kV} .1954$ 359 movies were collected at a super-resolution pixel size of $0.558 \AA$, a defocus range of $-0.6 \mu \mathrm{m}$ to -1.8 $360 \mu \mathrm{m}$ and a total exposure of $50 \mathrm{e}^{-} / \AA^{2}$ using SerialEM ${ }^{45}$. Images were processed as described below.

361 After evaluation of the first dataset, a second dataset was collected on a Titan Krios G3i microscope 362 operating at an acceleration voltage of $300 \mathrm{kV}$, equipped with a Gatan $\mathrm{K} 3$ direct electron detector 363 operating in CDS mode ${ }^{46}$ and a GIF Quantum energy filter with a $20-\mathrm{eV}$ slit width. 12,051 movies 364 were acquired with SerialEM in super-resolution counting mode with a super-resolution pixel size of $3650.525 \AA$ using an image shift collection scheme with active beam tilt correction, a defocus range from $366-0.5 \mu \mathrm{m}$ to $-1.6 \mu \mathrm{m}$ and a total electron exposure of $50 \mathrm{e}^{-/} / \AA^{2}$.

\section{Image processing}


bioRxiv preprint doi: https://doi.org/10.1101/2021.11.15.468712; this version posted November 15, 2021. The copyright holder for this preprint (which was not certified by peer review) is the author/funder, who has granted bioRxiv a license to display the preprint in perpetuity. It is made available under aCC-BY-NC-ND 4.0 International license.

Structures of the Cyanobacterial Phycobilisome

368 All movies were aligned, gain corrected and binned by 2 using MotionCorr2 as implemented in 369 RELION $3{ }^{47}$. The background streptavidin lattice in the motion corrected micrographs was subtracted 370 using in-house scripts ${ }^{30}$. These subtracted micrographs were then imported into Cryosparc ${ }^{48}$ for patch 371 CTF estimation and further image processing. For dataset 1 from the Talos Arctica microscope, 372 particles were picked using the blob picker, extracted with a box size of 720 pixels, and subjected to 373 one round of 2D classification. Good classes representing different views of the PBS were selected 374 and used as templates for a second round of autopicking, yielding $\sim 156,000$ particles. After another 375 round of 2D classification, $\sim 43,000$ particles in good classes were used to generate an ab-initio model 376 of the PBS. A subsequent round of heterogenous refinement using this reference yielded two distinct 377 classes representing the $\mathrm{PBS}^{\text {up-down }}(66 \%)$ and PBS ${ }^{\text {up-up }}(34 \%)$ conformations. These classes were 378 refined to $4.1 \AA$ and $4.5 \AA$, respectively.

379 For dataset 2 from the Titan Krios microscope, particles were picked from 800 micrographs using 380 templates generated from the PBS ${ }^{\text {up-up }}$ reconstructions from dataset 1 . After $2 \mathrm{D}$ classification and 381 heterogenous refinement three distinct classes corresponding to PBS ${ }^{\text {up-down }}$, PBS $^{\text {up-up }}$ and $\mathrm{PBS}^{\text {down-down }}$ 382 conformations became apparent. Using these classes as references, 11,903 micrographs were picked 383 to yield $\sim 1,900,000$ particles. After several rounds of heterogenous refinement, approximately 510,000 384 good particles were sorted into four classes representing the three conformations (PBS ${ }^{\text {up-down }}$ 50.6\%, 385 PBS up-up 38.9\%, and PBS ${ }^{\text {down-down }} 10.5 \%$ ). Refinement of the three conformations yielded overall 386 resolutions of $2.7 \AA$ (PBS $\left.{ }^{\text {up-up }}\right), 2.8 \AA\left(\mathrm{PBS}^{\text {up-down }}\right)$ and $3.5 \AA$ (PBS $\left.{ }^{\text {down-down }}\right)$.

387 During initial rounds of 2D classification of the datasets, we observed that several classes 388 corresponded to PBS-rods that aligned independently of the core section of the PBS. To obtain 389 reconstructions of the rods, these classes were used as templates for autopicking on a subset of 500 390 micrographs of dataset 2 and extracted with a box size of 360 pixels. $2 \mathrm{D}$ classification followed by ab391 initio model generation and heterogenous refinement yielded a particle set that reached a resolution of $3922.9 \AA$ during non-uniform refinement. Using the same templates for picking from the entire dataset 2 , 
bioRxiv preprint doi: https://doi.org/10.1101/2021.11.15.468712; this version posted November 15, 2021. The copyright holder for this preprint (which was not certified by peer review) is the author/funder, who has granted bioRxiv a license to display the preprint in perpetuity. It is made available under aCC-BY-NC-ND 4.0 International license.

Structures of the Cyanobacterial Phycobilisome

$393 \sim 2,100,000$ good particles were obtained that refined to a resolution $2.1 \AA$ after CTF refinement, 394 reaching Nyquist frequency. Further classification of the particle set to distinguish between different 395 rod protomers within one PBS complex was unsuccessful and always yielding the same conformation. 396 To visualize the contact area between two neighboring rods in the PBS ${ }^{\text {up-down }}$ conformation, particle 397 subtraction followed by local refinement was carried out on the PBS ${ }^{\text {up-down }}$ reconstruction. The map 398 yielded an improved resolution of $2.6 \AA$.

399 All processing was carried out using $\mathrm{C} 1$ symmetry and resolutions were estimated with the FSC = 4000.143 criterion $^{49}$. Reconstructions were sharpened using DeepEMhancer ${ }^{50}$ with the default tight mask 401 preset.

\section{Atomic model building and refinement}

403 Using our PBS-OCP ${ }^{\mathrm{R}}$ atomic models as a basis ${ }^{41}$, atomic models of the PBS core were refined using 404 a cropped PBS ${ }^{\text {up-down }}$ map with the real space refinement program in PHENIX 1.19.2 (ref. ${ }^{51}$ ). Similarly, 405 models of the core of other PBS conformations were refined but found to be virtually identical. Models 406 of the PBS-OCP ${ }^{\mathrm{R}}$ rod were used as a basis for refinement of the PBS rod. To arrive at models for all 407 three holo-PBS complexes, maps and models for the individual rods were rigid-body docked into the 408 density of each holo-PBS conformer, which resulted in an unambiguous orientation of each rod. 409 Because the holo-PBS maps are not resolved enough in the distal rod regions to allow for model 410 refinement, models of the full complexes are for visualization only.

\section{LC-MS/MS analysis of the PBS SDS-PAGE fractions}

412 Gel bands were digested in-gel according to ${ }^{52}$ with modifications. Briefly, gel bands were dehydrated 413 using $100 \%$ acetonitrile and incubated with $10 \mathrm{mM}$ dithiothreitol in $100 \mathrm{mM}$ ammonium bicarbonate, $414 \mathrm{pH} \sim 8$, at $56^{\circ} \mathrm{C}$ for $45 \mathrm{~min}$, dehydrated again and incubated in the dark with $50 \mathrm{mM}$ iodoacetamide in $415100 \mathrm{mM}$ ammonium bicarbonate for $20 \mathrm{~min}$. Gel bands were then washed with ammonium bicarbonate 
Structures of the Cyanobacterial Phycobilisome

and dehydrated again. Sequencing grade modified trypsin was prepared to $0.01 \mu \mathrm{g} / \mu \mathrm{l}$ in $50 \mathrm{mM}$ ammonium bicarbonate and $\sim 100 \mu 1$ of this was added to each gel band so that the gel was completely submerged. Bands were then incubated at $37^{\circ} \mathrm{C}$ overnight. Peptides were extracted from the gel by water bath sonication in a solution of $60 \%$ Acetonitrile (ACN) $/ 1 \%$ Trifluoroacetic acid (TFA) and vacuum dried to $\sim 2 \mu$ l.

Dried samples were re-suspended to $20 \mu \mathrm{l}$ in $2 \% \mathrm{ACN} / 0.1 \%$ TFA and an injection of $5 \mu \mathrm{l}$ was automatically made using a Thermo (www.thermo.com) EASYnLC 1000 onto a Thermo Acclaim PepMap RSLC $0.1 \mathrm{~mm} \times 20 \mathrm{~mm}$ C18 trapping column and washed for $\sim 5 \mathrm{~min}$ with buffer A. Bound peptides were then eluted over 35 min onto a Thermo Acclaim PepMap RSLC $0.075 \mathrm{~mm}$ x 250mm resolving column with a gradient of 5\%B to $40 \% \mathrm{~B}$ in $24 \mathrm{~min}$, ramping to $90 \% \mathrm{~B}$ at $25 \mathrm{~min}$ and held at $90 \% \mathrm{~B}$ for the duration of the run (Buffer $\mathrm{A}=99.9 \%$ water $/ 0.1 \%$ formic acid, Buffer $\mathrm{B}=80 \%$ acetonitrile $/ 0.1 \%$ formic acid $/ 19.9 \%$ water) at a constant flow rate of $300 \mathrm{nl} / \mathrm{min}$. Column temperature was maintained at a constant temperature of $50{ }^{\circ} \mathrm{C}$ using and integrated column oven (PRSO-V1, Sonation GmbH, Biberach, Germany).

Eluted peptides were sprayed into a ThermoScientific Q-Exactive mass spectrometer (www.thermo.com) using a FlexSpray spray ion source. Survey scans were taken in the Orbitrap (70,000 resolution, determined at $\mathrm{m} / \mathrm{z} 200$ ) and the top 15 ions in each survey scan are then subjected to automatic higher energy collision induced dissociation (HCD) with fragment spectra acquired at 17,500 resolution. The resulting MS/MS spectra are converted to peak lists using Mascot Distiller, v2.7.1 (www.matrixscience.com), and searched against a database containing all Synechocystis PCC 6803 protein sequences and appended with common laboratory contaminants (downloaded 2020-1117 from www.uniprot.org and www.thegpm.org, respectively) using the Mascot searching algorithm, v2.7. The Mascot output was then analyzed using Scaffold, v5.0 (www.proteomesoftware.com) to probabilistically validate protein identifications. Assignments validated using the Scaffold 1\%FDR confidence filter are considered true. 
Structures of the Cyanobacterial Phycobilisome

441 Thee performed LC-MS/MS on the protein bands to confirm the identity of all the PBS components

442 (Extended Data Table 2).

\section{Modelling the energy flow within PBS complex.}

444 Excitation energy transfer within PBS was studied in the limit of the Förster theory, using dipole445 dipole approximation for the inter-pigment coupling. The energy transfer rates $k$ (in $\mathrm{ps}^{-1}$ ) were 446 computed using the equation ${ }^{53}$ :

$$
k_{i j}=1.18 V^{2} \mathrm{~J}
$$

448 where $J$ is the spectral overlap between donor emission and acceptor absorption, and the coupling $V$ 449 (in $\left.\mathrm{cm}^{-1}\right)$ is given by

$$
V=5.04 \frac{\mu_{i} \mu_{j} \kappa}{R^{3}}
$$

451 where $R$ is the center-to-center dipole separation in nm, $k$ is the orientation factor, and $\mu_{i}$ and $\mu_{j}$ are the

452 transition dipole moments (in Debye) of the donor and acceptor, respectively. We have used effective 453 transition dipole moments, including the correction for the effect of dielectric properties of the protein 454 (see ref. ${ }^{53}$ for discussion of this point). The direction of the pigment transition dipoles of bilin 455 chromophores were placed along the axis of the conjugated parts of the molecules. The geometrical 456 axis was obtained using the singular-value decomposition on the atom coordinates. For bilins, the 457 transition dipole moment of $13 \mathrm{D}$ were used for the bilins in rod (CPC), and $15 \mathrm{D}$ for bilins in the core 458 (APC) pigments ${ }^{54}$. The spectral overlap $J$ is calculated from the area-normalized spectra of donor and 459 acceptor reported in literature ${ }^{34,55,56}$. Using the full matrix of the excitation transfer rates computed 460 using (1), it is possible to write down a master equation describing the time evolution of probability of 461 exciton residence on $i$-th chromophore, with a vector-valued $y(t)=y_{i}(\mathrm{t})$ (for $i$ running from 1 to the 462 number of pigments):

$$
\frac{d \boldsymbol{y}(t)}{d t}=\boldsymbol{K} \cdot \boldsymbol{y}(t)
$$


Structures of the Cyanobacterial Phycobilisome

where $\boldsymbol{K}$ represents the transition matrix whose off-diagonal elements $\left(K_{i j}\right)$ represent the pairwise rates of energy transfer, $k_{\mathrm{ij}}$, between donor $(i)$ and acceptor $(j)$ pigments. The diagonal elements are defined as:

$$
K_{i i}=-\left(k_{i i}^{0}+\sum_{i, i \neq j} k_{i j}\right)
$$

where $k_{i i}^{0}$ corresponds to the intrinsic excited state decay rate of the $i$-th pigment; we used $k_{i i}^{0}=(1500$ ps $)^{-1}$ for all bilins, except for b-84, which was assigned the lifetime of $900 \mathrm{ps,} \mathrm{based} \mathrm{on}{ }^{57}$, however, the exact value of this parameter has little effect on the simulation results. Solving (3) for initial conditions given as $y_{i}(0)=1$ for $i=k$, and $y_{i}(0)=0$ for $i \neq k$, yields the model for the excitation flow through the PBS following excitation into $k$-th pigment. A sum of $y_{i}(t)$ over $i$ then describes the total decay of the excitation in the PBS. The validity of the model was tested by comparing the results with experimental data reported earlier. Extended Data Fig. 7 shows that correspondence between the simulation and experimental data is reasonable, considering that the model was not in any way adjusted to fit the experimental data and is based solely on the structural information and previously reported pigment spectra.

\section{Bioinformatics}

Homologues of ApcG were found by searching with a profile HMM (constructed from sll1873 homologs obtained by BLAST search) against 420 non-redundant UniProt proteomes that contained a complete PBS protein set (as described in ref. $^{41}$ ). Sequences of the 50 proteomes with a protein composition closest to Synechocystis PCC 6803 were used for sequence alignments. Sequences were aligned Clustal $\mathrm{W}^{58,59}$, trimmed with trimAl ${ }^{60}$ and the protein sequence conservation was visualized with Weblogo $3.74^{61}$.Homologues of ApcG were found by searching with a profile HMM (constructed from sll1873 homologs obtained by BLAST search) against 420 non-redundant UniProt proteomes 
Structures of the Cyanobacterial Phycobilisome

that contained a complete PBS protein set (as described in ref. ${ }^{41}$ ). Sequences of the 50 proteomes with a protein composition closest to Synechocystis PCC 6803 were used for sequence alignments. Sequences were aligned ClustalW $\mathrm{W}^{58,59}$, trimmed with trim $\mathrm{Al}^{60}$ and the protein sequence conservation was visualized with Weblogo $3.74^{61}$.

Structures were analyzed with ChimeraX ${ }^{62}$ and Pymol (The PyMOL Molecular Graphics System, version 1.7 Schrödinger, LLC).

\section{Acknowledgements}

CAK and MADM would like to dedicate this manuscript to Dr. Nicole Tandeau de Marsac. The authors want to thank Dr. Bryan Ferlez for taking TEM images. We thank Dr. Douglas Whitten from the Proteomic Facility at Michigan State University, A. Chintangal and P. Tobias for computational support, Dr. Daniel Toso and Jonathan Remis at the Cal-Cryo facility for support with cryo-EM data collection, Dr. Robert Glaeser and Dr. Bong-Gyoon Han for advice concerning streptavidin grid preparation, and Dr. Lisa Eshun-Wilson for help with data processing. Research in the Kerfeld lab was supported by the Office of Science of the U.S. Department of Energy DE-FG02-91ER20021. This project has received funding from the European Union's Horizon 2020 research and innovation programme under the Marie Sklodowska-Curie grant agreement No. 795070. DB and TP thank the Czech Science Foundation, grant No. 19-28323X. DB also acknowledges institutional support RVO:60077344. Molecular graphics and analyses were performed with UCSF ChimeraX with support from NIH R01-GM129325. E.N. is a Howard Hughes Medical Investigator.

\section{Author contributions}

MADM and PVS designed and performed experiments, interpreted results. CK designed and supervised the project. HK helped with the sample preparation, interpreted results. MS refined the structures and interpreted results. DB and TP performed the model for the energy transfer. BJG 
Structures of the Cyanobacterial Phycobilisome

511 performed initial characterization of the specimen for cryo-EM. MADM, PVS and CK wrote the

512 manuscript with help from all authors.

\section{Competing interest}

514 The authors declare no competing interests.

\section{Data availability}

516 The atomic coordinates have been deposited in the Protein Data Bank with the accession codes 7SC8

517 for the rod and 7SC7 for the PBS ${ }^{\text {up-down }}$ core.

518 The EM maps have been deposited in the Electron Microscopy Data Bank with the accession codes

51925029 for the rod, 25028 for the $\mathrm{PBS}^{\text {up-down }}$ core, 25069 for the full map of the $\mathrm{PBS}^{\text {up-down }}$ conformation

520 and the rod-rod contact, 25070 for the full map of the PBS ${ }^{\text {down-down }}$ conformation and 25071 for the

521 full map of the PBS up-up conformation.

522 All other data are available from the corresponding authors upon reasonable request. 
bioRxiv preprint doi: https://doi org/10.1101/2021.11.15,468712; this version posted November 15,2021 . The copyright holder for this preprint (which was not certified by peer review) is the author/funder, who has granted bioRxiv a license to display the preprint in perpetuity. It is made available under aCC-BY-NC-ND 4.0 International license.

Structures of the Cyanobacterial Phycobilisome

\section{Extended Data}

524 Extended Data Table 1: Synechocystis PCC 6803 Phycobilisome Protein subunits. (*) Nomenclature used along the text.

525 (**) New linker discovered and incorporated in this study.

\begin{tabular}{|c|c|c|c|c|c|c|c|}
\hline $\begin{array}{c}\text { Protein } \\
\text { component }\end{array}$ & $\begin{array}{l}\text { Gene } \\
\text { symbol }\end{array}$ & $\begin{array}{c}\text { Protein } \\
\text { name }\left({ }^{*}\right)\end{array}$ & Function & pfam & $\begin{array}{l}\text { \#bilins per } \\
\text { monomer }\end{array}$ & $\begin{array}{l}\text { \#proteins } \\
\text { per PBS }\end{array}$ & $\mathrm{MW}(\mathrm{kDa})$ \\
\hline$\alpha-\mathrm{PC}$ & $c p c A$ & CpcA & $\begin{array}{c}\text { Rod } \\
\text { antenna } \\
\text { protein }\end{array}$ & pfam00502 & $1 \mathrm{PCB}$ & 108 & 17.6 \\
\hline$\beta-\mathrm{PC}$ & $c p c B$ & $\mathrm{CpcB}$ & $\begin{array}{c}\text { Rod } \\
\text { antenna } \\
\text { protein }\end{array}$ & pfam00502 & $2 \mathrm{PCB}$ & 108 & 18.1 \\
\hline $\mathrm{L}_{\mathrm{R} 33}$ & $c p c C l$ & $\mathrm{CpcC1}$ & $\begin{array}{c}\text { Internal rod } \\
\text { linker }\end{array}$ & $\begin{array}{l}\text { pfam00427/ } \\
\text { pfam01383 }\end{array}$ & -- & 6 & 32.5 \\
\hline $\mathrm{L}_{\mathrm{R} 30}$ & $c p c C 2$ & $\mathrm{CpcC} 2$ & $\begin{array}{c}\text { Internal rod } \\
\text { linker }\end{array}$ & $\begin{array}{l}\text { pfam00427/ } \\
\text { pfam01383 }\end{array}$ & -- & 6 & 30.8 \\
\hline $\mathrm{L}_{\mathrm{R} 10}$ & $c p c D$ & $\mathrm{CpcD}$ & $\begin{array}{c}\text { Internal rod } \\
\text { linker }\end{array}$ & pfam01383 & -- & 6 & 9.3 \\
\hline $\mathrm{L}_{\mathrm{RC}}$ & $c p c G 1$ & CpcG1 & $\begin{array}{c}\text { Rod-to-core } \\
\text { linker }\end{array}$ & pfam00427 & -- & 6 & 28.9 \\
\hline $\mathrm{L}_{\mathrm{RC}}$ & $c p c G 2$ & CpcG2 & $\begin{array}{c}\text { Rod-to-core } \\
\text { linker }\end{array}$ & pfam00427 & -- & -- & 28.5 \\
\hline$\alpha-\mathrm{APC}$ & apcA & ApcA & $\begin{array}{c}\text { Major core } \\
\text { antenna } \\
\text { protein }\end{array}$ & pfam00502 & $1 \mathrm{PCB}$ & 32 & 17.4 \\
\hline$\beta$-APC & $a p c B$ & ApcB & $\begin{array}{c}\text { Major core } \\
\text { antenna } \\
\text { protein }\end{array}$ & pfam 00502 & $1 \mathrm{PCB}$ & 34 & 17.2 \\
\hline
\end{tabular}


bioRxiv preprint doi: https://doi.org/10.1101/2021.11.15.468712; this version posted November 15, 2021. The copyright holder for this

preprint (which was not certified by peer review) is the author/funder, who has granted bioRxiv a license to display the preprint in perpetuity. It is made available under aCC-BY-NC-ND 4.0 International license.

Structures of the Cyanobacterial Phycobilisome

\begin{tabular}{|c|c|c|c|c|c|c|c|}
\hline $\mathrm{L}_{\mathrm{C}}$ & $a p c C$ & ApcC & $\begin{array}{c}\text { Internal } \\
\text { core protein }\end{array}$ & pfam01383 & -- & 6 & 7.7 \\
\hline $\mathrm{L}_{\mathrm{CM}}$ & $a p c E$ & ApcE & $\begin{array}{l}\text { Core-to- } \\
\text { membrane } \\
\text { linker }\end{array}$ & $\begin{array}{l}\text { pfam00427/ } \\
\text { pfam00502 }\end{array}$ & $1 \mathrm{PCB}$ & 2 & 100.3 \\
\hline$\alpha-\mathrm{B}$ & $a p c D$ & ApcD & $\begin{array}{c}\text { Minor core } \\
\text { antenna } \\
\text { protein }\end{array}$ & pfam00502 & $1 \mathrm{PCB}$ & 2 & 17.9 \\
\hline$\alpha-B 18$ & $a p c F$ & $\mathrm{ApcF}$ & $\begin{array}{c}\text { Minor core } \\
\text { antenna } \\
\text { protein }\end{array}$ & pfam00502 & $1 \mathrm{PCB}$ & 2 & 18.9 \\
\hline $\mathrm{L}_{\mathrm{C} 10^{* *}}$ & $a p c G$ & ApcG & Linker & $\begin{array}{c}\text { Newly } \\
\text { discovered } \\
\text { no assigned } \\
\text { pfam }\end{array}$ & -- & 2 & 12.9 \\
\hline
\end{tabular}


bioRxiv preprint doi: https://doi org/10.1101/2021.11 15,468712; this version posted November $15,2021$. The copyright holder for this

preprint (which was not certified by peer review) is the author/funder, who has granted bioRxiv a license to display the preprint in perpetuity. It is made available under aCC-BY-NC-ND 4.0 International license.

Structures of the Cyanobacterial Phycobilisome

527 Extended Data Table 2: MS analysis of the Synechocystis PCC 6803 Phycobilisome Protein subunits. The criteria were

5282 peptides, False Discovery Rate $(F D R)=1 \%$, percentage of coverage (\% coverage) $>30 \%$, and the number of total

529 peptide count of each protein (\# total peptide count). $M W(\mathrm{kDa})=$ Molecular Weight assigned by the software used in the 530 analysis, Scaffold 5.0 software.

\begin{tabular}{|c|c|c|c|c|}
\hline $\begin{array}{c}\text { Protein } \\
\text { component }\end{array}$ & Gene symbol & $\begin{array}{c}\text { \# total peptide } \\
\text { count }\end{array}$ & $\%$ coverage & MW (kDa) \\
\hline$\alpha-\mathrm{PC}$ & $c p c A$ & 420 & 94 & 18 \\
\hline$\beta-\mathrm{PC}$ & $c p c B$ & 414 & 93 & 18 \\
\hline $\mathrm{L}_{\mathrm{R} 33}$ & $c p c C 1$ & 236 & 61 & 33 \\
\hline $\mathrm{L}_{\mathrm{R} 30}$ & $c p c C 2$ & 219 & 60 & 31 \\
\hline $\mathrm{L}_{\mathrm{R} 10}$ & $c p c D$ & 148 & 88 & 9 \\
\hline $\mathrm{L}_{\mathrm{RC}}$ & $c p c G 1$ & 215 & 83 & 27 \\
\hline $\mathrm{L}_{\mathrm{RC}}$ & $c p c G 2$ & 21 & 43 & 29 \\
\hline$\alpha-\mathrm{APC}$ & apcA & 224 & 93 & 17 \\
\hline$\beta$-APC & $a p c B$ & 322 & 94 & 17 \\
\hline $\mathrm{L}_{\mathrm{C}}$ & $\operatorname{apcC}$ & 86 & 63 & 8 \\
\hline $\mathrm{L}_{\mathrm{CM}}$ & $a p c E$ & 671 & 72 & 100 \\
\hline$\alpha-B$ & $a p c D$ & 61 & 83 & 18 \\
\hline$\alpha-B 18$ & $a p c F$ & 66 & 71 & 19 \\
\hline $\mathrm{L}_{\mathrm{c} 10}$ & $a p c G$ & 27 & 78 & 13 \\
\hline FNR & petH & 177 & 78 & 46 \\
\hline$\alpha-\mathrm{PC}$ & $c p c A$ & 420 & 94 & 18 \\
\hline$\beta-\mathrm{PC}$ & $c p c B$ & 414 & 93 & 18 \\
\hline $\mathrm{L}_{\mathrm{R} 33}$ & $c p c C 1$ & 236 & 61 & 33 \\
\hline LR30 & $c p c C 2$ & 219 & 60 & 31 \\
\hline LR10 & $c p c D$ & 148 & 88 & 9 \\
\hline LRC & $c p c G 1$ & 215 & 83 & 27 \\
\hline $\mathrm{L}_{\mathrm{RC}}$ & $c p c G 2$ & 21 & 43 & 29 \\
\hline FNR & petH & 177 & 78 & 46 \\
\hline
\end{tabular}


bioRxiv preprint doi: https://doi.org/10.1101/2021.11.15.468712; this version posted November 15, 2021. The copyright holder for this preprint (which was not certified by peer review) is the author/funder, who has granted bioRxiv a license to display the preprint in perpetuity. It is made available under aCC-BY-NC-ND 4.0 International license.

Structures of the Cyanobacterial Phycobilisome

Extended Data Table 3: Cryo-EM data collection, refinement and validation statistics

\begin{tabular}{|c|c|c|c|c|c|c|c|}
\hline $\begin{array}{l}\text { EMD } \\
\text { PDB }\end{array}$ & PBS up-up & $\mathrm{PBS}^{\text {up-down }}$ & $\begin{array}{l}\text { PBS }{ }^{\text {up-up }} \\
25071\end{array}$ & $\begin{array}{l}\text { PBS }^{\text {up-down }} \\
25069\end{array}$ & $\begin{array}{l}\text { PBS }^{\text {up-down }} \text { core } \\
25028 \\
7 \mathrm{SC} 7\end{array}$ & $\begin{array}{l}\text { PBS }^{\text {down-down }} \\
25070\end{array}$ & $\begin{array}{l}\text { Rod } \\
25029 \\
7 \mathrm{SC} 8\end{array}$ \\
\hline Dataset & \multicolumn{2}{|l|}{1} & \multicolumn{5}{|c|}{2} \\
\hline $\begin{array}{l}\text { Data collection and processing } \\
\text { Magnification } \\
\text { Voltage }(\mathrm{kV}) \\
\text { Electron exposure }\left(\mathrm{e}-/ \AA^{2}\right) \\
\text { Defocus range }(\mu \mathrm{m}) \\
\text { Pixel size }(\AA) \\
\text { Symmetry imposed } \\
\text { Initial particle images (no.) } \\
\text { Final particle images (no.) } \\
\text { Map resolution }(\AA) \\
\text { FSC threshold } 0.143 \\
\text { Map resolution range }(\AA) \\
\\
\text { Refinement } \\
\text { Initial model used }(\mathrm{PDB} \text { code) } \\
\text { Model resolution }(\AA) \\
\text { FSC threshold } 0.5 \\
\text { Model composition } \\
\text { Non-hydrogen atoms } \\
\text { Protein residues } \\
\text { Ligands } \\
B \text { factors }\left(\AA^{2}\right) \\
\text { Protein } \\
\text { Ligand } \\
\text { R.m.s. deviations } \\
\text { Bond lengths }(\AA) \\
\text { Bond angles }\left({ }^{\circ}\right) \\
\text { Validation } \\
\text { MolProbity score } \\
\text { Clashscore } \\
\text { Poor rotamers }(\%) \\
\text { Ramachandran plot } \\
\text { Favored }(\%) \\
\text { Allowed }(\%) \\
\text { Disallowed (\%) } \\
\text { Mon }\end{array}$ & $\begin{array}{lr} & 3600 \\
& 200 \\
& 50 \\
& \\
& 0.6-1 \\
& 1.11 \\
& \text { C1 } \\
& \\
& 156,0 \\
14,434 & \\
4.5 & \\
\text { (C2 imposed) } \\
\text { N/A } \\
\text { N/A }\end{array}$ & $\begin{array}{l}0 \\
28,109 \\
4.2 \\
\text { N/A } \\
\text { N/A }\end{array}$ & $\begin{array}{l}135,701 \\
2.7 \\
2.5-10\end{array}$ & & 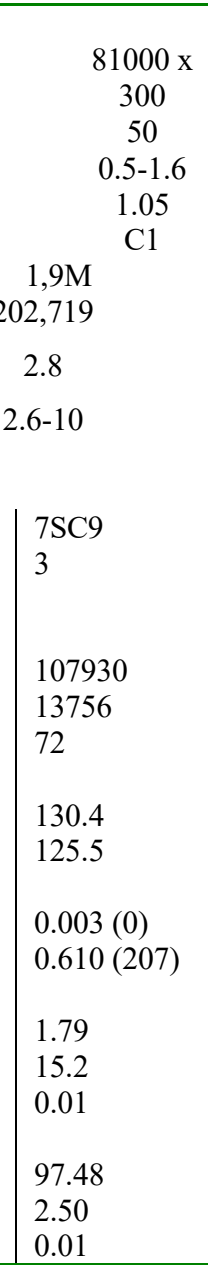 & $\begin{array}{l}52,674 \\
3.5 \\
3.2-10\end{array}$ & $\begin{array}{l}6.6 \mathrm{M} \\
2.1 \mathrm{M} \\
2.1 \\
\\
2.1-2.5 \\
\\
7 \mathrm{SCA} \\
2.2 \\
\\
\\
54106 \\
6835 \\
54 \\
\\
88.8 \\
88.6 \\
\\
0.002(0) \\
0.793(13) \\
1.53 \\
10.2 \\
0.00 \\
98.9 \\
1.1 \\
0.00\end{array}$ \\
\hline
\end{tabular}




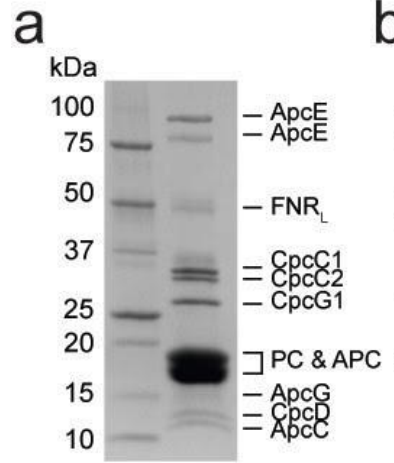

C

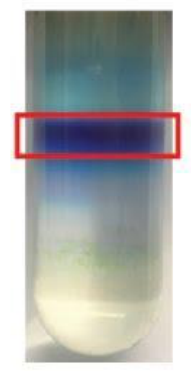

b

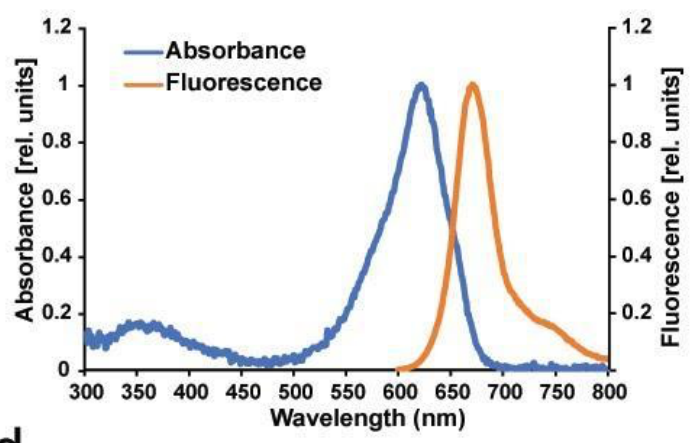

d

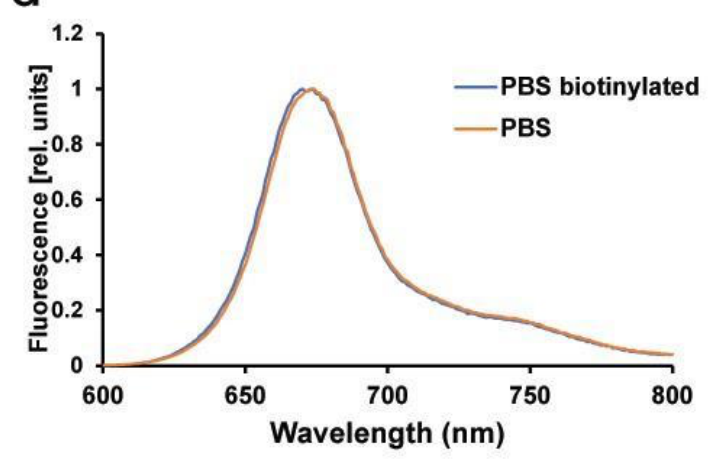

Extended Data Figure 1: Biochemical and spectroscopic PBS characterization. a, Protein composition analysis of the

535 PBS sample by SDS-PAGE. Identification of the components by MS can be found in Extended Data Table 2. b, Absorption,

536 and fluorescence spectrum of the isolated PBS in 0.75 M K-phosphate pH 7.5. The PBS shows a maximum absorbance at $537620 \mathrm{~nm}$ corresponding to phycocyanin (PC), and a shoulder at $650 \mathrm{~nm}$ corresponding to allophycocyanin (APC). The

538 fluorescence peak maximum is $\sim 670 \mathrm{~nm}$ when PC is preferentially excited (excitation at $580 \mathrm{~nm}$ ), and a shoulder from 740 $539 \mathrm{~nm}$ to $780 \mathrm{~nm}$. c, Sucrose gradient of PBS showing the intense blue band that was used for cryo-EM. d, Fluorescence 540 spectra of PBS before and after in vitro biotinylation. Collectively, these data show that the PBS preparation was 541 structurally and functionally intact. 
bioRxiv preprint doi: https://doi.org/10.1101/2021.11.15.468712; this version posted November 15,2021 . The copyright holder for this preprint (which was not certified by peer review) is the author/funder, who has granted bioRxiv a license to display the preprint in perpetuity. It is made available under aCC-BY-NC-ND 4.0 International license.

Structures of the Cyanobacterial Phycobilisome

a

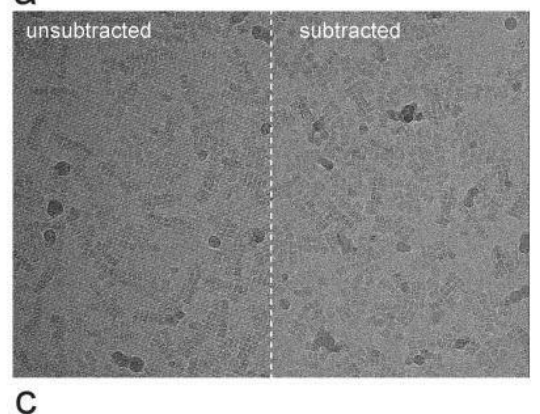

Motion correction, lattice subtraction, CTF estimation 236,961 particles from 800 micrographs, $720 \mathrm{px}$

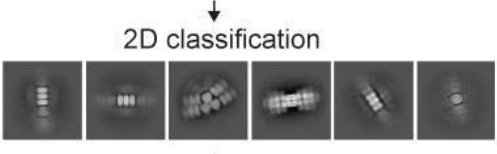

$\downarrow$

$2 \mathrm{x}$ heterogeneous refinement $(42,549$ particles)



$\frac{40 \%}{\downarrow}$

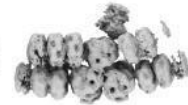

$27 \%$

mplate based picking and extraction

$1,894,163$ particles from 11,903 micrographs

$$
\downarrow
$$

$3 x$ heterogeneous refinement (509,724 particles)
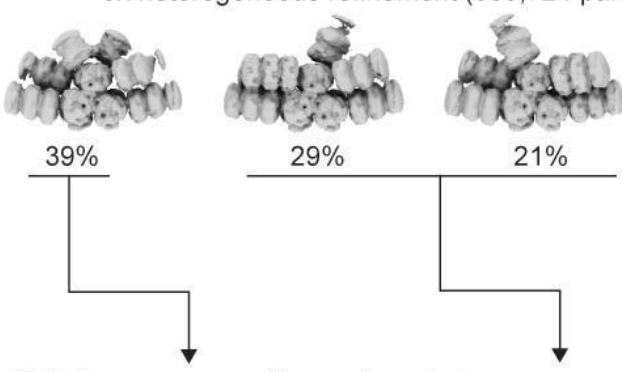

$2 x$ heterogeneous refinement, homogeneous refinement (135,701 particles)
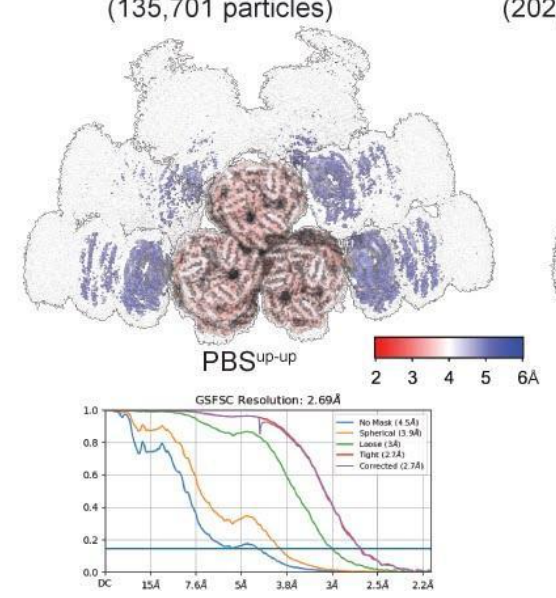

$21 \%$ b

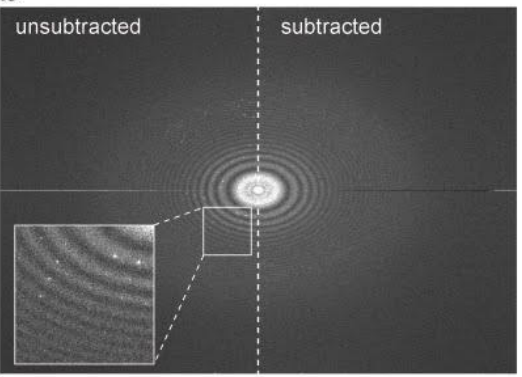

192,514 particles from 500 micrographs, 360px

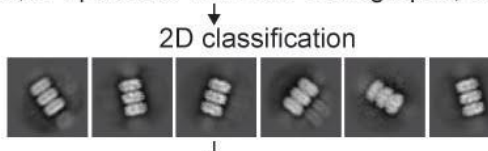

model generation \&

use rod classes to pick heterogeneous refinement $(67,600$ particles)
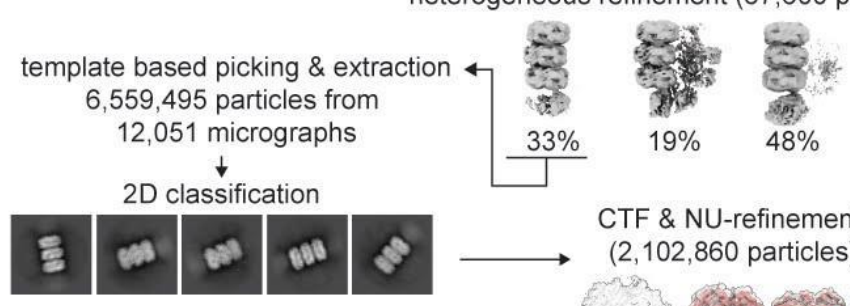

CTF \& NU-refinement

(2,102,860 particles)



Rod
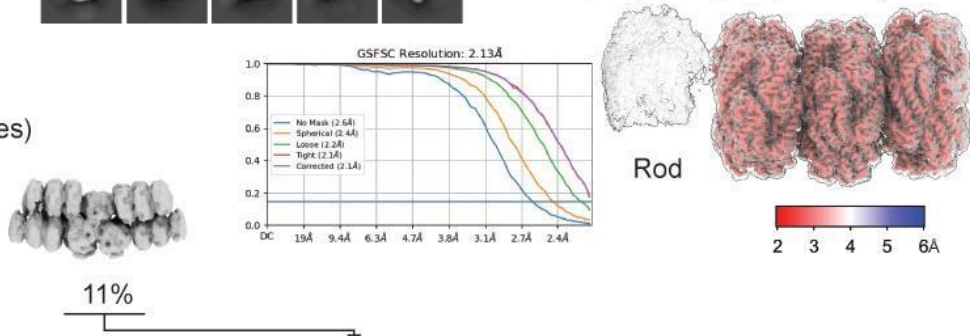

$1 \%$

homogeneous refinement (52,674 particles)
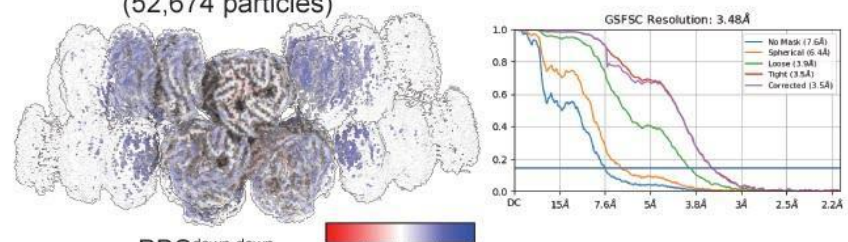

543 Extended Data Figure 2: Cryo-EM data processing of PBS data. a, Example raw micrograph before and after

544 streptavidin lattice subtraction. b, Fourier transform of a showing Bragg diffraction of streptavidin crystal before subtraction. c, Processing pipeline of dataset 2, yielding the structures presented in this paper. Red to blue color shadings 
bioRxiv preprint doi: https://doi.org/10.1101/2021.11.15.468712; this version posted November 15, 2021. The copyright holder for this

preprint (which was not certified by peer review) is the author/funder, who has granted bioRxiv a license to display the preprint in perpetuity. It is made available under aCC-BY-NC-ND 4.0 International license.

\section{Structures of the Cyanobacterial Phycobilisome}

represent local resolution estimates at FSC $=0.5$ ranging from 2 to 6 A. The three PBS conformations and the structure of

547 the rod are shown at two different thresholds to visualize both overall shape and higher resolution details. 
bioRxiv preprint doi: https://doi org/10.1101/2021.11.15.468712; this version posted November 15,2021 . The copyright holder for this preprint (which was not certified by peer review) is the author/funder, who has granted bioRxiv a license to display the preprint in perpetuity. It is made available under aCC-BY-NC-ND 4.0 International license.

Structures of the Cyanobacterial Phycobilisome

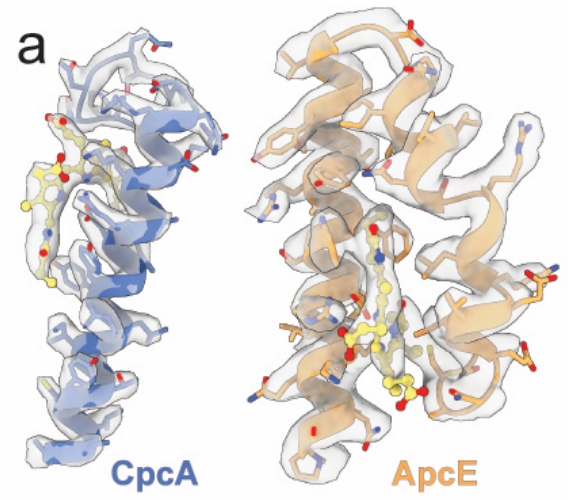

b


C

PBS rod
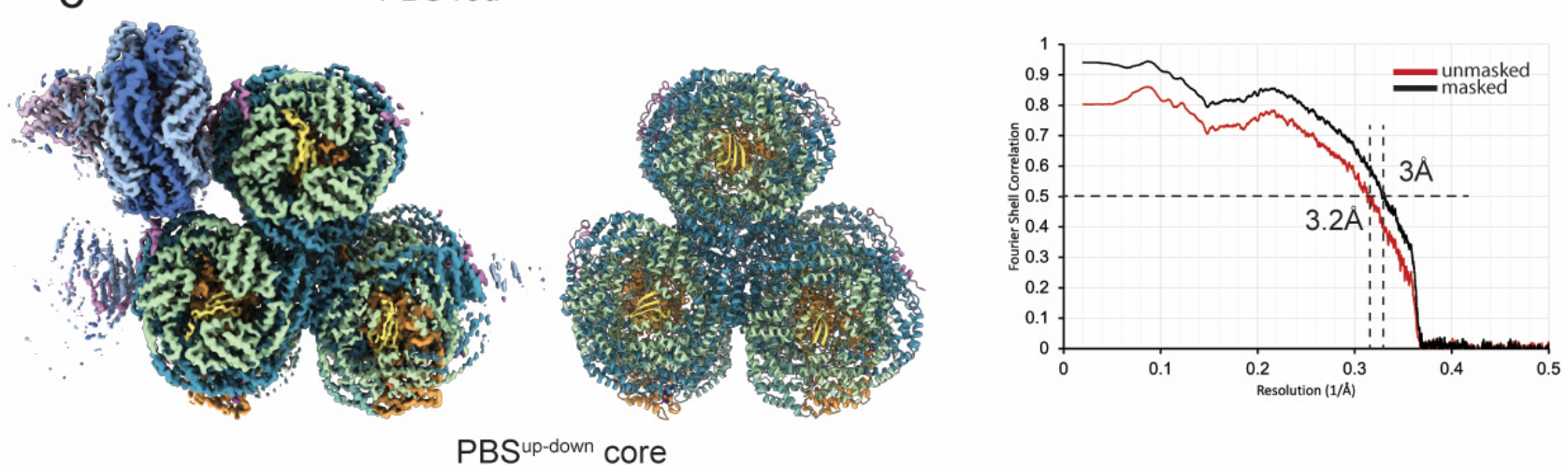

PBSup-down core

549 Extended Data Figure 3: Map and Model quality of PBS ${ }^{u p-d o w n}$. a, EM density examples of CpcA, ApcE and associated

550 bilins showing map quality of the $P B S^{u p-d o w n} . \boldsymbol{b}$ and $\boldsymbol{c}$, Cropped $P B S^{u p-d o w n}$ map, model and corresponding Fourier shell 551 correlation (FSC) curves. Resolution of masked and unmasked models are indicated at FSC $=0.5$. 
bioRxiv preprint doi: https://doi org/10.1101/2021.11.15.468712; this version posted November 15,2021 . The copyright holder for this preprint (which was not certified by peer review) is the author/funder, who has granted bioRxiv a license to display the preprint in perpetuity. It is made available under aCC-BY-NC-ND 4.0 International license.

Structures of the Cyanobacterial Phycobilisome

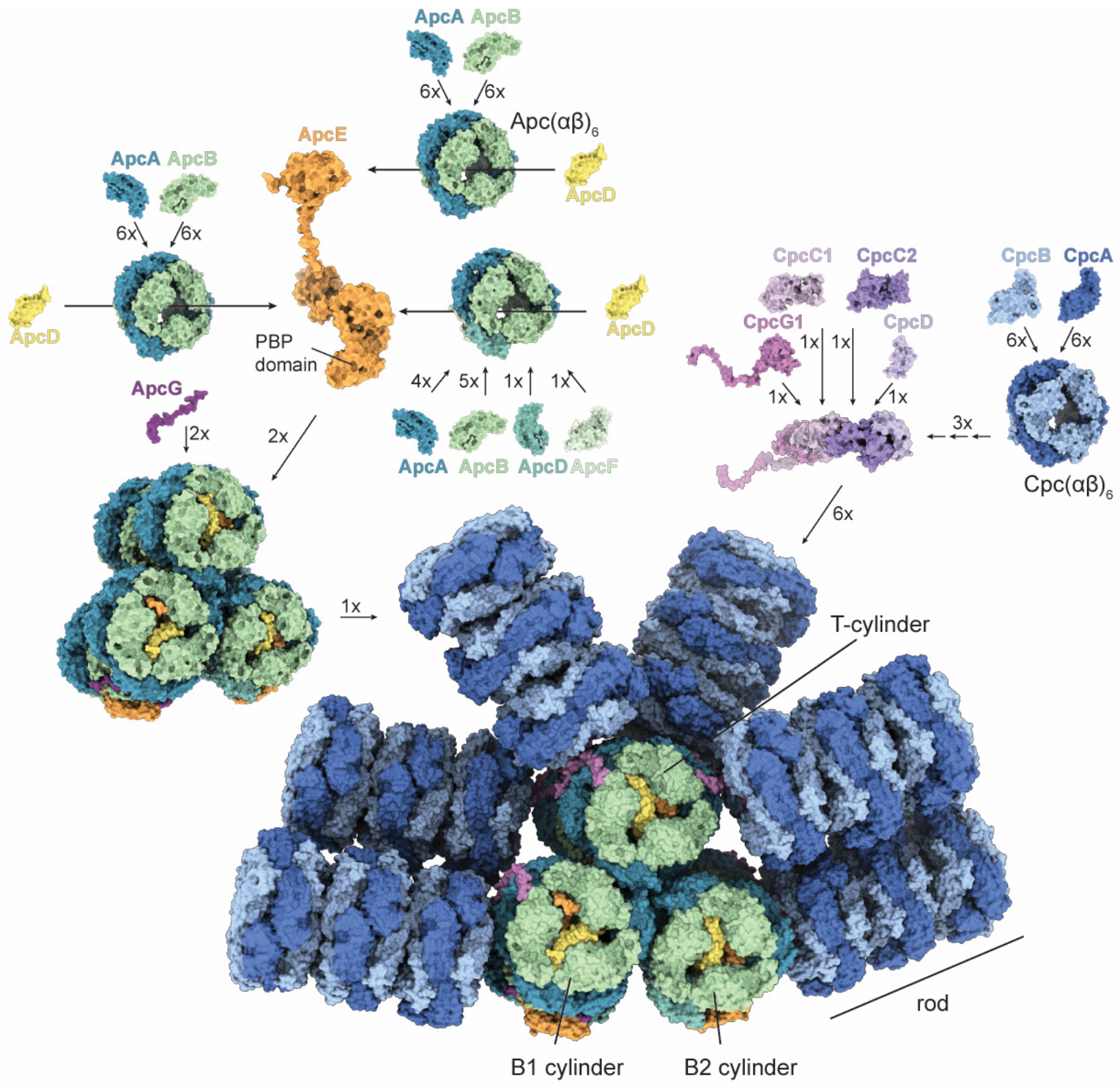

core

553 Extended Data Figure 4: Assembly of the PBS. The core cylinders consist of four stacked discs; each disc contains three

$554 \alpha$ - and three $\beta$-type Apc proteins that form the signature $(\alpha \beta)_{6}$ hexamers. Besides the canonical ApcA and ApcB proteins,

$555 B 1$ and B2 cylinders contain one copy each of $A p c D$ and $A p c F$, as well as the phycobiliprotein domain of ApcE. These are

556 symmetrically arranged in the two bottom cylinders, oriented towards the membrane. ApcG. ApcD and ApcE protrude out

557 of the core, indicating their likely role in contacting the photosystems. Each rod contains three stacked discs, each

558 consisting of one CpcA/B hexamer. The overall architecture of the PBS core is in agreement with modelling predictions ${ }^{29}$. 
bioRxiv preprint doi: https://doi.org/10.1101/2021.11.15.468712; this version posted November 15,2021 . The copyright holder for this preprint (which was not certified by peer review) is the author/funder, who has granted bioRxiv a license to display the preprint in perpetuity. It is made available under aCC-BY-NC-ND 4.0 International license.

Structures of the Cyanobacterial Phycobilisome
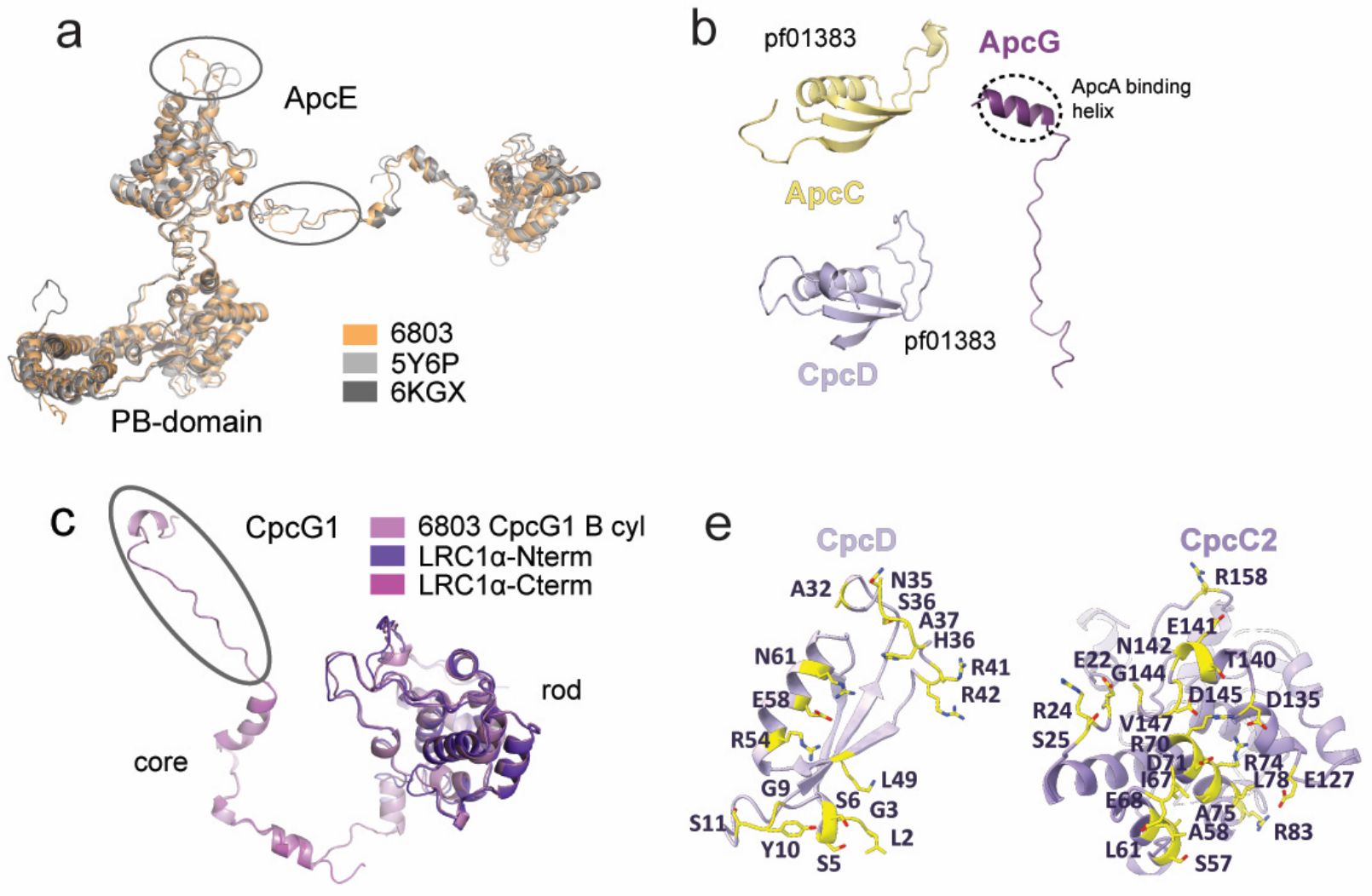

f
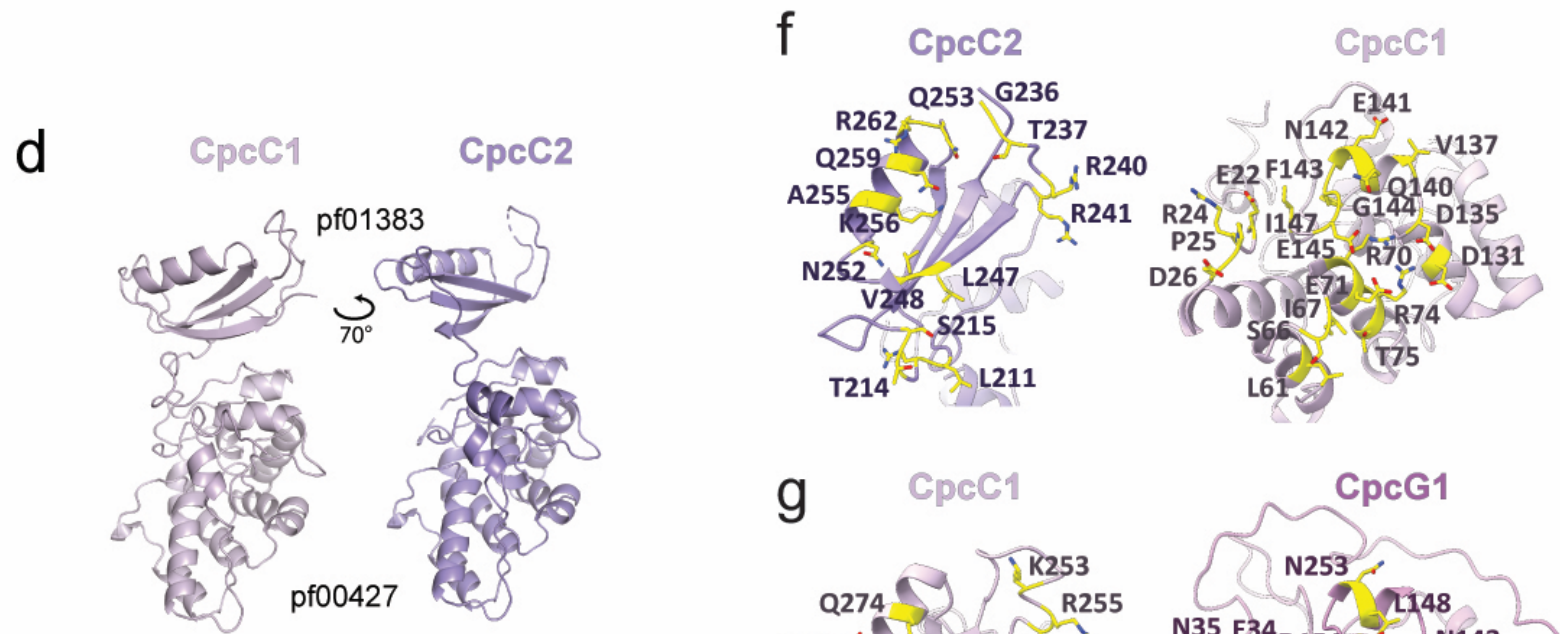

$\mathrm{h}$
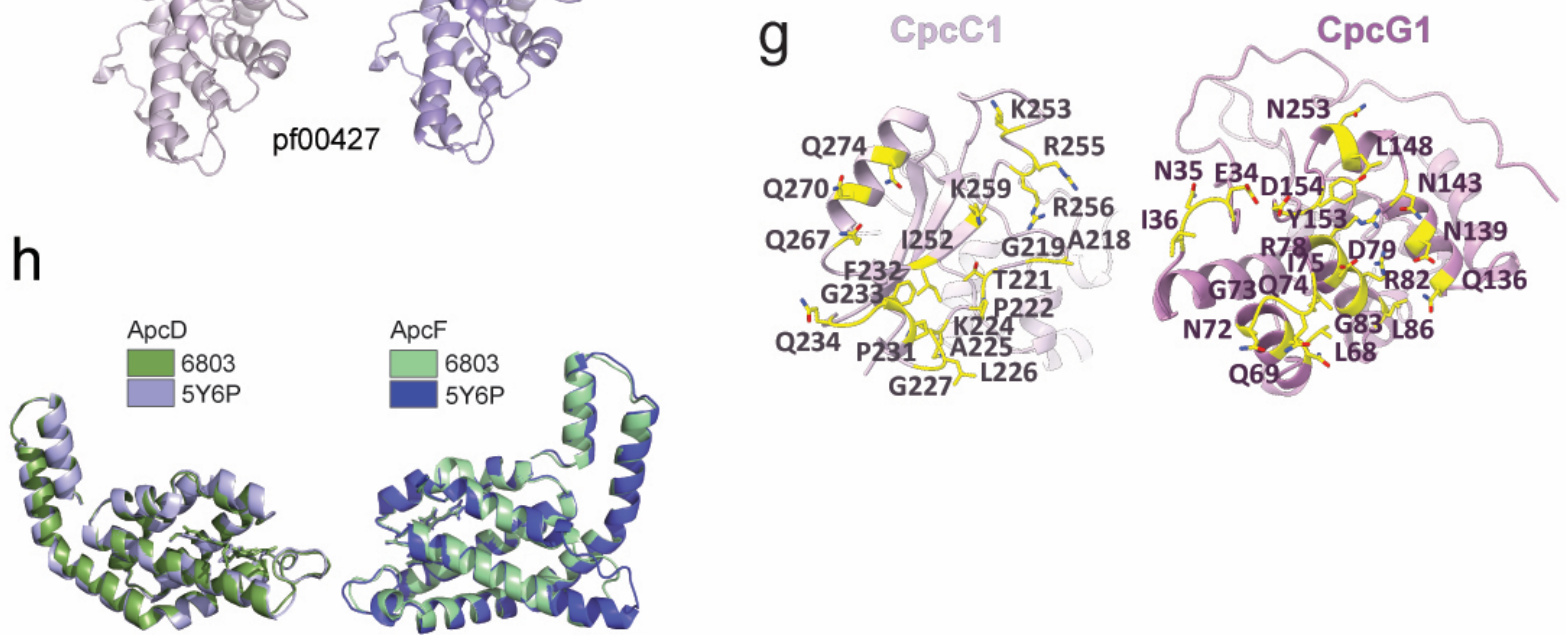

560 Extended Data Figure 5: Molecular details of the PBS. a, Alignment of ApcE with red algae homologs (PDB:5Y6P

561 Griffithsia pacifica, PDB:6KGX Porphyridium purpureum). RMSD is 1.9 A, differences are circled. $\boldsymbol{b}$, Structural models 562 of ApcC, ApcG and CpcD. CpcD and ApcC consist of a single pf01383 domain. c, Alignment of CpcG1 with red algae 


\section{Structures of the Cyanobacterial Phycobilisome}

563 homologs. Circle in CpcG1 shows C-terminal domain. CpcG1 is related to algal LRC1 linker with RMSD of 0.7 A in the

564 pf00427 domain. The C-terminal domain of CpcG1 has homology to LRCla with RMSD of 0.6 A. d, Comparison of CpcCl

565 and $C p c C 2$. e-g, interaction between $C p c D, C p c C 2, C p c C 1$ and $C p c G 1$. Interacting residues are highlighted. $\boldsymbol{h}$, Alignment

566 of $A p c D$ and ApcF with red algae homologs. ApcD is related to the red algal homolog with RMSD of 0.6 A while ApcF

567 aligns with an RMSD of 0.6 A with its homolog. The only major differences exist in loop regions. 
bioRxiv preprint doi: https://doi org/10.1101/2021.11.15.468712; this version posted November 15,2021 . The copyright holder for this preprint (which was not certified by peer review) is the author/funder, who has granted bioRxiv a license to display the preprint in perpetuity. It is made available under aCC-BY-NC-ND 4.0 International license.

Structures of the Cyanobacterial Phycobilisome

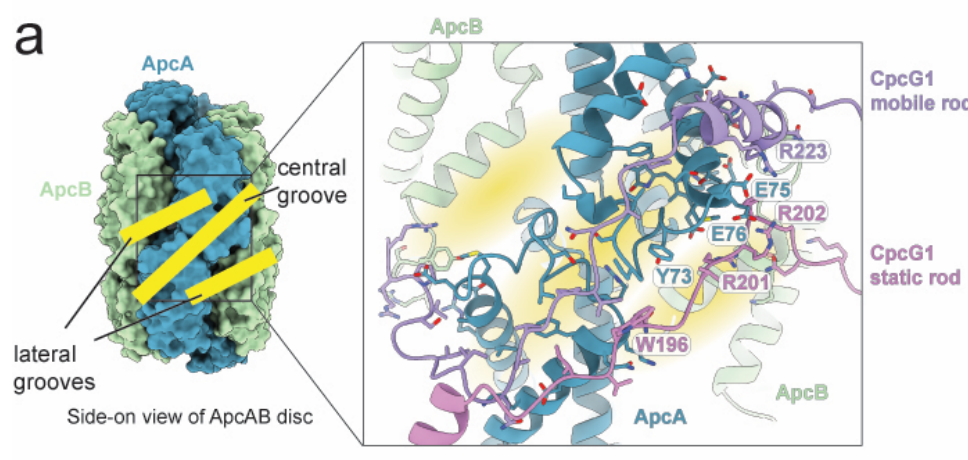

570 Extended Data Figure 6: PBS rod conformation. a, Side view of AcpAB disc showing the groove network that organizes

571 CpcG1 linker attachment to the PBS core. Selected residues are labeled. $\boldsymbol{b}$, Salt bridge formed between two neighboring

572 rods when the mobile rod adopts the 'down' conformation. EM density is transparent, dark grey and shows the 573

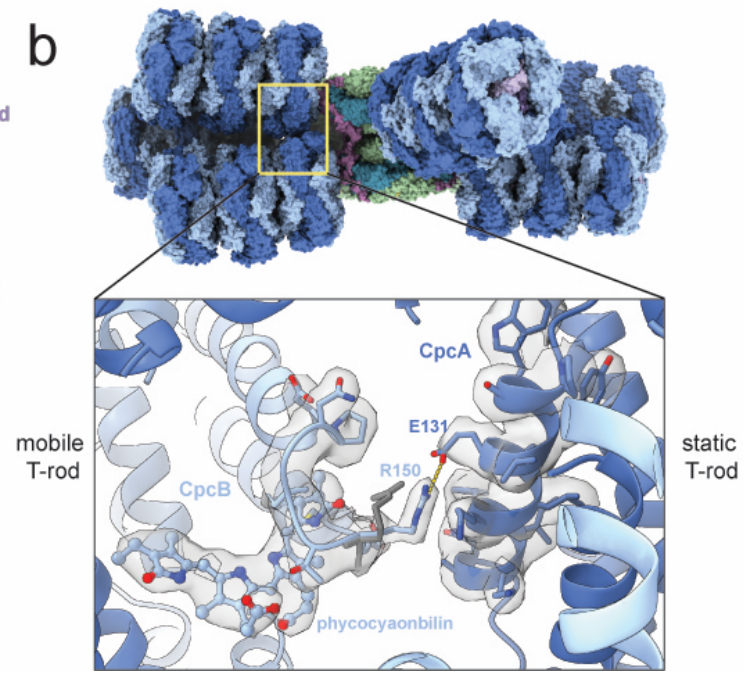


bioRxiv preprint doi: https://doi.org/10.1101/2021.11.15.468712; this version posted November 15,2021 . The copyright holder for this preprint (which was not certified by peer review) is the author/funder, who has granted bioRxiv a license to display the preprint in perpetuity. It is made available under aCC-BY-NC-ND 4.0 International license.

Structures of the Cyanobacterial Phycobilisome

a
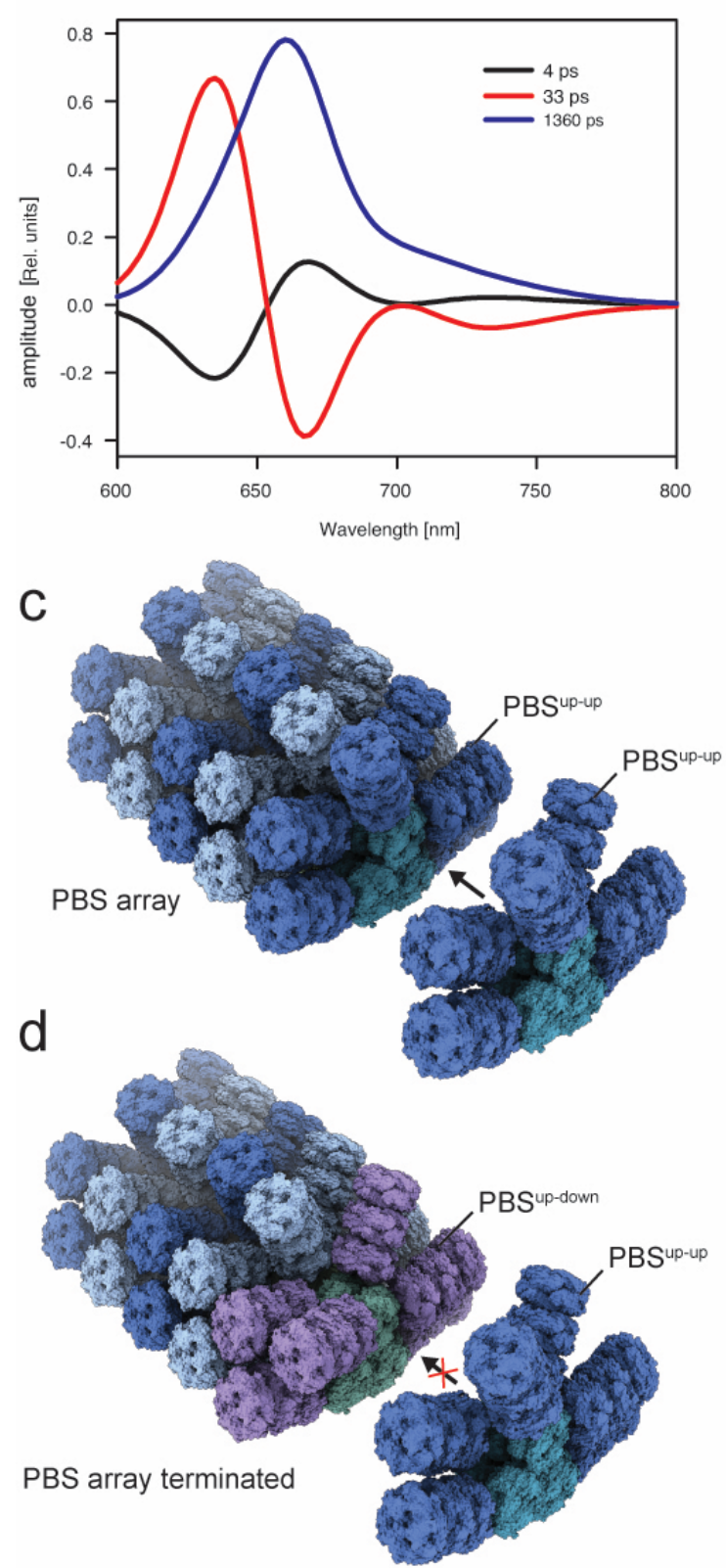

b

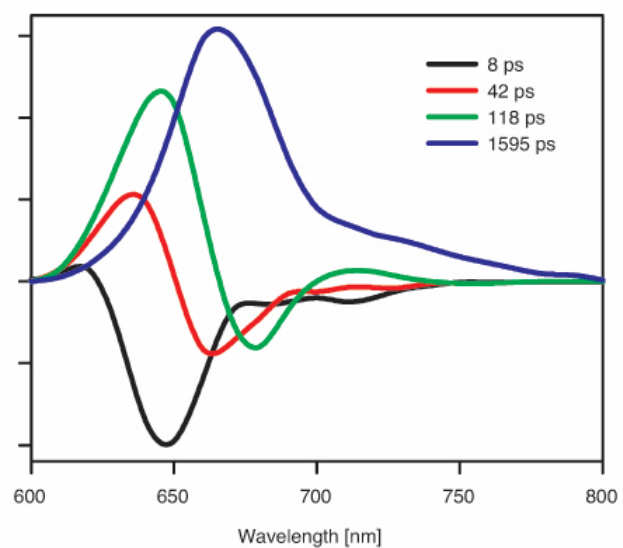

e

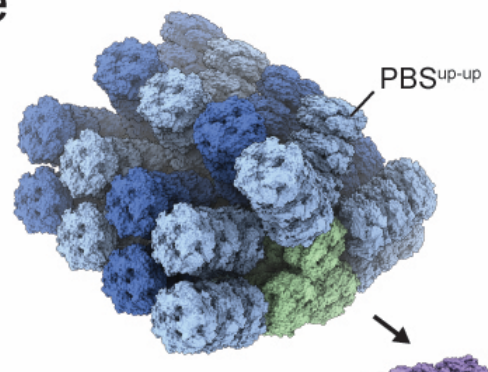

PBS array dispersion

575 Extended Data Figure 7: Decay associated spectra (DAS) and PBS arrays. DAS spectra obtained either a, from

576 simulation or $\boldsymbol{b}$, from fitting the data obtained from time-resolved fluorescence (right, adapted from ref. ${ }^{34}$ ) monitoring the

577 excitation energy flow in the PBS. In simulations, PBS was excited into the far end of the rod. The 100 ps component

578 (green) in the experimental data was interpreted as due to excitation annihilation ${ }^{35}$, hence it is not present in the simulation.

$579 c$, PBS arrays were modeled based on cryo-electron tomography data from ref.40. a, only the up-up conformation is 580 compatible with PBS arrays. $\boldsymbol{d}$, The up-down conformation would result in array termination. $\boldsymbol{e}$, A PBS switching to the down-down conformation could result in array dispersion. 
bioRxiv preprint doi: https://doi.org/10.1101/2021.11.15.468712; this version posted November 15, 2021. The copyright holder for this preprint (which was not certified by peer review) is the author/funder, who has granted bioRxiv a license to display the preprint in perpetuity. It is made available under aCC-BY-NC-ND 4.0 International license.

Structures of the Cyanobacterial Phycobilisome

\section{$\underline{\text { References }}$}

5831 Sanchez-Baracaldo, P., Bianchini, G., Wilson, J. D. \& Knoll, A. H. Cyanobacteria and 584 biogeochemical cycles through Earth history. Trends Microbiol, doi:10.1016/j.tim.2021.05.008 (2021).

2 Kumar, J., Singh, D., Tyagi, M. B. \& Kumar, A. Cyanobacteria: Applications in Biotechnology. Cyanobacteria: From Basic Science to Applications, 327-346, doi:10.1016/B978-0-12-8146675.00016-7 (2019).

588

3 Gantt, E. \& Conti, S. F. Phycobiliprotein localization in algae. Brookhaven Symp Biol 19, 393405 (1966).

592 Gantt, E. \& Conti, S. F. Granules associated with the chloroplast lamellae of Porphyridium cruentum. J Cell Biol 29, 423-434, doi:10.1083/jcb.29.3.423 (1966).

5 Tandeau de Marsac, N. Phycobiliproteins and phycobilisomes: the early observations. Photosynth Res 76, 193-205, doi:10.1023/A:1024954911473 (2003).

6 Grossman, A. R., Schaefer, M. R., Chiang, G. G. \& Collier, J. L. The phycobilisome, a lightharvesting complex responsive to environmental conditions. Microbiol Rev 57, 725-749, doi:10.1128/mr.57.3.725-749.1993 (1993).

7 de Marsac, N. T. \& Cohen-bazire, G. Molecular composition of cyanobacterial phycobilisomes. Proc Natl Acad Sci U S A 74, 1635-1639, doi:10.1073/pnas.74.4.1635 (1977).

8 Adir, N. Elucidation of the molecular structures of components of the phycobilisome: reconstructing a giant. Photosynth Res 85, 15-32, doi:10.1007/s11120-004-2143-y (2005).

9 Glauser, M. et al. Phycobilisome structure in the cyanobacteria Mastigocladus laminosus and Anabaena sp. PCC 7120. Eur J Biochem 205, 907-915, doi:10.1111/j.14321033.1992.tb16857.x (1992).

10 Ducret, A., Sidler, W., Wehrli, E., Frank, G. \& Zuber, H. Isolation, characterization and electron microscopy analysis of a hemidiscoidal phycobilisome type from the cyanobacterium Anabaena sp. PCC 7120. Eur J Biochem 236, 1010-1024, doi:10.1111/j.14321033.1996.01010.x (1996).

Ducret, A. et al. Reconstitution, characterisation and mass analysis of the pentacylindrical allophycocyanin core complex from the cyanobacterium Anabaena sp. PCC 7120. J Mol Biol 278, 369-388, doi:10.1006/jmbi.1998.1678 (1998).

12 Anderson, L. K. \& Toole, C. M. A model for early events in the assembly pathway of cyanobacterial phycobilisomes. Mol Microbiol 30, 467-474, doi:10.1046/j.13652958.1998.01081.x (1998).

13 Schirmer, T., Bode, W. \& Huber, R. Refined three-dimensional structures of two cyanobacterial C-phycocyanins at 2.1 and 2.5 A resolution. A common principle of phycobilinprotein interaction. J Mol Biol 196, 677-695, doi:10.1016/0022-2836(87)90040-4 (1987). Schirmer, T. et al. Crystal structure analysis and refinement at $2.5 \mathrm{~A}$ of hexameric Cphycocyanin from the cyanobacterium Agmenellum quadruplicatum. The molecular model and its implications for light-harvesting. J Mol Biol 188, 651-676, doi:10.1016/s00222836(86)80013-4 (1986).

Zhang, J. et al. Structure of phycobilisome from the red alga Griffithsia pacifica. Nature 551, 57-63, doi:10.1038/nature24278 (2017).

$6 \mathrm{Ma}$, J. et al. Structural basis of energy transfer in Porphyridium purpureum phycobilisome. Nature 579, 146-151, doi:10.1038/s41586-020-2020-7 (2020). 
bioRxiv preprint doi: https://doi.org/10.1101/2021.11.15.468712; this version posted November 15, 2021. The copyright holder for this preprint (which was not certified by peer review) is the author/funder, who has granted bioRxiv a license to display the preprint in perpetuity. It is made available under aCC-BY-NC-ND 4.0 International license.

Structures of the Cyanobacterial Phycobilisome

626

627

628

629

630

631

632

633

634

635

636

637

638

639

640

641

642

643

644

645

646

647

648

649

650

651

652

653

654

655

656

657

658

659

660

661

662

663

664

665

666

667

668

669

670

671

672

17 Zheng, L. et al. Structural insight into the mechanism of energy transfer in cyanobacterial phycobilisomes. Nat Commun 12, 5497, doi:10.1038/s41467-021-25813-y (2021).

18 MacColl, R. Cyanobacterial phycobilisomes. J Struct Biol 124, 311-334, doi:10.1006/jsbi.1998.4062 (1998).

19 Glazer, A. N. Light guides. Directional energy transfer in a photosynthetic antenna.J Biol Chem 264, 1-4 (1989).

20 Gantt, E. \& Lipschultz, C. A. Phycobilisomes of Porphyridium cruentum. I. Isolation. J Cell Biol 54, 313-324, doi:10.1083/jcb.54.2.313 (1972).

21 Arteni, A. A. et al. Structure and organization of phycobilisomes on membranes of the red alga Porphyridium cruentum. Photosynth Res 95, 169-174, doi:10.1007/s11120-007-9264-z (2008).

22 Arteni, A. A., Ajlani, G. \& Boekema, E. J. Structural organisation of phycobilisomes from Synechocystis sp. strain PCC6803 and their interaction with the membrane. Biochim Biophys Acta 1787, 272-279, doi:10.1016/j.bbabio.2009.01.009 (2009).

23 Williams, R. C., Gingrich, J. C. \& Glazer, A. N. Cyanobacterial phycobilisomes. Particles from Synechocystis 6701 and two pigment mutants. J Cell Biol 85, 558-566, doi:10.1083/jcb.85.3.558 (1980).

24 Yamanaka, G., Glazer, A. N. \& Williams, R. C. Molecular architecture of a light-harvesting antenna. Comparison of wild type and mutant Synechococcus 6301 phycobilisomes. J Biol Chem 255, 11104-11110 (1980).

25 Chang, L. et al. Structural organization of an intact phycobilisome and its association with photosystem II. Cell Res 25, 726-737, doi:10.1038/cr.2015.59 (2015).

26 Guglielmi, G., Cohenbazire, G. \& Bryant, D. A. The Structure of Gloeobacter-Violaceus and Its Phycobilisomes. Arch Microbiol 129, 181-189, doi:Doi 10.1007/Bf00425248 (1981).

27 Mills, L. A., McCormick, A. J. \& Lea-Smith, D. J. Current knowledge and recent advances in understanding metabolism of the model cyanobacterium Synechocystis sp. PCC 6803. Biosci Rep 40, doi:10.1042/BSR20193325 (2020).

28 Adir, N., Bar-Zvi, S. \& Harris, D. The amazing phycobilisome. Biochim Biophys Acta Bioenerg 1861, 148047, doi:10.1016/j.bbabio.2019.07.002 (2020).

29 Liu, H. et al. Structure of cyanobacterial phycobilisome core revealed by structural modeling and chemical cross-linking. Sci Adv 7, doi:10.1126/sciadv.aba5743 (2021).

30 Han, B. G. et al. Long shelf-life streptavidin support-films suitable for electron microscopy of biological macromolecules. J Struct Biol 195, 238-244, doi:10.1016/j.jsb.2016.06.009 (2016).

31 Mullineaux, C. W. Phycobilisome-reaction centre interaction in cyanobacteria. Photosynthesis Research 95, 175-182, doi:10.1007/s11120-007-9249-y (2008).

32 Calzadilla, P. I., Muzzopappa, F., Setif, P. \& Kirilovsky, D. Different roles for ApcD and ApcF in Synechococcus elongatus and Synechocystis sp. PCC 6803 phycobilisomes. Biochim Biophys Acta Bioenerg 1860, 488-498, doi:10.1016/j.bbabio.2019.04.004 (2019).

33 Dong, C. et al. ApcD is necessary for efficient energy transfer from phycobilisomes to photosystem I and helps to prevent photoinhibition in the cyanobacterium Synechococcus sp. PCC 7002. Biochim Biophys Acta 1787, 1122-1128, doi:10.1016/j.bbabio.2009.04.007 (2009).

34 Tian, L. et al. Picosecond kinetics of light harvesting and photoprotective quenching in wildtype and mutant phycobilisomes isolated from the cyanobacterium Synechocystis PCC 6803. Biophys J 102, 1692-1700, doi:10.1016/j.bpj.2012.03.008 (2012).

35 van Stokkum, I. H. M. et al. A functional compartmental model of the Synechocystis PCC 6803 phycobilisome. Photosynth Res 135, 87-102, doi:10.1007/s11120-017-0424-5 (2018). 
bioRxiv preprint doi: https://doi.org/10.1101/2021.11.15.468712; this version posted November 15, 2021. The copyright holder for this preprint (which was not certified by peer review) is the author/funder, who has granted bioRxiv a license to display the preprint in perpetuity. It is made available under aCC-BY-NC-ND 4.0 International license.

Structures of the Cyanobacterial Phycobilisome

36 Xie, M. et al. Difference in light use strategy in red alga between Griffithsia pacifica and Porphyridium purpureum. Sci Rep 11, 14367, doi:10.1038/s41598-021-93696-6 (2021).

37 Kruger, T. P. J., van Grondelle, R. \& Gwizdala, M. The role of far-red spectral states in the energy regulation of phycobilisomes. Biochim Biophys Acta Bioenerg 1860, 341-349, doi:10.1016/j.bbabio.2019.01.007 (2019).

38 Glazer, A. N., Lundell, D. J., Yamanaka, G. \& Williams, R. C. The structure of a "simple" phycobilisome. Ann Microbiol (Paris) 134B, 159-180, doi:10.1016/s0769-2609(83)80103-3 (1983).

39 Liu, H. et al. Phycobilisomes supply excitations to both photosystems in a megacomplex in cyanobacteria. Science 342, 1104-1107, doi:10.1126/science.1242321 (2013).

40 Rast, A. et al. Biogenic regions of cyanobacterial thylakoids form contact sites with the plasma membrane. Nat Plants 5, 436-446, doi:10.1038/s41477-019-0399-7 (2019).

41 Dominguez-Martin, M. A. et al. Structure of the quenched cyanobacterial OCP-phycobilisome complex. Submitted.

42 Araoz, R. \& Hader, D. P. Ultraviolet radiation induces both degradation and synthesis of phycobilisomes in Nostoc sp.: a spectroscopic and biochemical approach. Fems Microbiol Ecol 23, 301-313, doi:10.1111/j.1574-6941.1997.tb00411.x (1997).

43 Gantt, E., Lipschultz, C. A., Grabowski, J. \& Zimmerman, B. K. Phycobilisomes from blue-green and red algae: isolation criteria and dissociation characteristics. Plant Physiol 63, 615-620, doi:10.1104/pp.63.4.615 (1979).

44 Tivol, W. F., Briegel, A. \& Jensen, G. J. An improved cryogen for plunge freezing. Microsc Microanal 14, 375-379, doi:10.1017/S1431927608080781 (2008).

45 Schorb, M., Haberbosch, I., Hagen, W. J. H., Schwab, Y. \& Mastronarde, D. N. Software tools for automated transmission electron microscopy. Nat Methods 16, 471-477, doi:10.1038/s41592-019-0396-9 (2019).

46 Sun, M. et al. Practical considerations for using K3 cameras in CDS mode for high-resolution and high-throughput single particle cryo-EM. J Struct Biol 213, 107745, doi:10.1016/j.jsb.2021.107745 (2021).

47 Scheres, S. H. RELION: implementation of a Bayesian approach to cryo-EM structure determination. J Struct Biol 180, 519-530, doi:10.1016/j.jsb.2012.09.006 (2012).

48 Punjani, A., Rubinstein, J. L., Fleet, D. J. \& Brubaker, M. A. cryoSPARC: algorithms for rapid unsupervised cryo-EM structure determination. Nat Methods 14, 290-296, doi:10.1038/nmeth.4169 (2017).

49 Rosenthal, P. B. \& Henderson, R. Optimal determination of particle orientation, absolute hand, and contrast loss in single-particle electron cryomicroscopy. J Mol Biol 333, 721-745, doi:10.1016/j.jmb.2003.07.013 (2003).

50 Sanchez-Garcia, R. et al. DeepEMhancer: a deep learning solution for cryo-EM volume postprocessing. Commun Biol 4, 874, doi:10.1038/s42003-021-02399-1 (2021).

51 Liebschner, D. et al. Macromolecular structure determination using X-rays, neutrons and electrons: recent developments in Phenix. Acta Crystallogr D Struct Biol 75, 861-877, doi:10.1107/S2059798319011471 (2019).

52 Shevchenko, A., Wilm, M., Vorm, O. \& Mann, M. Mass spectrometric sequencing of proteins silver-stained polyacrylamide gels. Anal Chem 68, 850-858, doi:10.1021/ac950914h (1996).

53 Pullerits, T., Hess, S., Herek, J. L. \& Sundstrom, V. Temperature dependence of excitation transfer in LH2 of Rhodobacter sphaeroides. Journal of Physical Chemistry B 101, 1056010567, doi:DOI 10.1021/jp9720956 (1997). 
bioRxiv preprint doi: https://doi org/10.1101/2021.11.15.468712; this version posted November 15, 2021. The copyright holder for this preprint (which was not certified by peer review) is the author/funder, who has granted bioRxiv a license to display the preprint in perpetuity. It is made available under ACC-BY-NC-ND 4.0 International license.

Structures of the Cyanobacterial Phycobilisome

719

720

721

722

723

724

725

726

727

728

729

730

731

732

733

734

735

736

737

738

739

740

741

742

743

54 Sauer, K. \& Scheer, H. Excitation Transfer in C-Phycocyanin - Forster Transfer Rate and Exciton Calculations Based on New Crystal-Structure Data for C-Phycocyanins from AgmenellumQuadruplicatum and Mastigocladus-Laminosus. Biochimica Et Biophysica Acta 936, 157-170, doi:Doi 10.1016/0005-2728(88)90232-0 (1988).

55 Demidov, A. A. \& Mimuro, M. Deconvolution of C-phycocyanin beta-84 and beta-155 chromophore absorption and fluorescence spectra of cyanobacterium Mastigocladus laminosus. Biophys J 68, 1500-1506, doi:10.1016/S0006-3495(95)80322-X (1995).

56 Fuente, D., Lazar, D., Oliver-Villanueva, J. V. \& Urchueguia, J. F. Reconstruction of the absorption spectrum of Synechocystis sp. PCC 6803 optical mutants from the in vivo signature of individual pigments. Photosynth Res 147, 75-90, doi:10.1007/s11120-020-00799-8 (2021).

57 Squires, A. H. \& Moerner, W. E. Direct single-molecule measurements of phycocyanobilin photophysics in monomeric C-phycocyanin. Proc Natl Acad Sci U S A 114, 9779-9784, doi:10.1073/pnas.1705435114 (2017).

58 Larkin, M. A. et al. Clustal W and Clustal X version 2.0. Bioinformatics 23, 2947-2948, doi:10.1093/bioinformatics/btm404 (2007).

59 Kozlov, A. M., Darriba, D., Flouri, T., Morel, B. \& Stamatakis, A. RAxML-NG: a fast, scalable and user-friendly tool for maximum likelihood phylogenetic inference. Bioinformatics 35, 44534455, doi:10.1093/bioinformatics/btz305 (2019).

60 Capella-Gutierrez, S., Silla-Martinez, J. M. \& Gabaldon, T. trimAl: a tool for automated alignment trimming in large-scale phylogenetic analyses. Bioinformatics 25, 1972-1973, doi:10.1093/bioinformatics/btp348 (2009).

61 Crooks, G. E., Hon, G., Chandonia, J. M. \& Brenner, S. E. WebLogo: a sequence logo generator. Genome Res 14, 1188-1190, doi:10.1101/gr.849004 (2004).

62 Goddard, T. D. et al. UCSF ChimeraX: Meeting modern challenges in visualization and analysis. Protein Sci 27, 14-25, doi:10.1002/pro.3235 (2018). 